Check for updates

Cite this: Chem. Sci., 2019, 10, 8840

๑ All publication charges for this article have been paid for by the Royal Society of Chemistry

Received 2nd May 2019

Accepted 6th August 2019

DOI: $10.1039 / c 9 s c 02149 c$

rsc.li/chemical-science

\section{Tuning the structure, reactivity and magnetic communication of nitride-bridged uranium complexes with the ancillary ligands $\uparrow$}

\author{
Chad T. Palumbo, (D) a Luciano Barluzzi, (DD) a Rosario Scopelliti, (D) a Ivica Zivkovic, (D) b \\ Alberto Fabrizio, (D) a Clémence Corminboeuf (D) *a and Marinella Mazzanti (D) *a
}

\begin{abstract}
Molecular uranium nitride complexes were prepared to relate their small molecule reactivity to the nature of the $U=N=U$ bonding imposed by the supporting ligand. The $U^{4+}-U^{4+}$ nitride complexes, $\left[N u_{4}\right]$ $\left.\left[\left\{\left({ }^{t} \mathrm{BuO}\right)_{3} \mathrm{SiO}\right)_{3} \mathrm{U}\right\}_{2}(\mu-\mathrm{N})\right], \quad\left[\mathrm{NBu}_{4}\right]-1$, and $\left.\left[\mathrm{NBu}_{4}\right]\left[\left(\left(\mathrm{Me}_{3} \mathrm{Si}\right)_{2} \mathrm{~N}\right)_{3} \mathrm{U}\right\}_{2}(\mu-\mathrm{N})\right], 2$, were synthesised by reacting $\mathrm{NBu}_{4} \mathrm{~N}_{3}$ with the $\mathrm{U}^{3+}$ complexes, $\left[\mathrm{U}\left(\mathrm{OSi}\left(\mathrm{O}^{t} \mathrm{Bu}\right)_{3}\right)_{2}\left(\mu-\mathrm{OSi}\left(\mathrm{O}^{t} \mathrm{Bu}\right)_{3}\right)\right]_{2}$ and $\left[\mathrm{U}\left(\mathrm{N}\left(\mathrm{SiMe}_{3}\right)_{2}\right)_{3}\right]$, respectively. Oxidation of 2 with $\mathrm{AgBPh}_{4}$ gave the $\mathrm{U}^{4+}-\mathrm{U}^{5+}$ analogue, [((Me $\left.\left.\left.3 \mathrm{Si}_{2} \mathrm{~N}\right)_{3} \mathrm{U}\right\}_{2}(\mu-\mathrm{N})\right]$, 4. The previously reported methylene-bridged $\mathrm{U}^{4+}-\mathrm{U}^{4+}$ nitride $\left[\mathrm{Na}(\mathrm{dme})_{3}\right]\left[\left(\left(\mathrm{Me} \mathrm{S}_{3} \mathrm{Si}\right)_{2}\right)_{2} \mathrm{U}(\mu-\mathrm{N})\left(\mu-\kappa^{2}-\mathrm{C}, \mathrm{N}-\mathrm{CH}_{2} \mathrm{SiMe}_{2} \mathrm{NSiMe}_{3}\right)\right.$ $\left.\mathrm{U}\left(\mathrm{N}\left(\mathrm{SiMe}_{3}\right)_{2}\right)_{2}\right]$ (dme = 1,2-dimethoxyethane), $\left[\mathrm{Na}(\mathrm{dme})_{3}\right]-3$, provided a versatile precursor for the synthesis of the mixed-ligand $\mathrm{U}^{4+}-\mathrm{U}^{4+}$ nitride complex, $\left[\mathrm{Na}(\mathrm{dme})_{3}\right]\left[\left(\left(\mathrm{Me}{ }_{3} \mathrm{Si}\right)_{2} \mathrm{~N}\right)_{3} \mathrm{U}(\mu-\mathrm{N})\right.$ $\left.\mathrm{U}\left(\mathrm{N}\left(\mathrm{SiMe}_{3}\right)_{2}\right)\left(\mathrm{OSi}\left(\mathrm{O}^{t} \mathrm{Bu}\right)_{3}\right)\right]$, 5. The reactivity of the 1-5 complexes was assessed with $\mathrm{CO}_{2}, \mathrm{CO}$, and $\mathrm{H}_{2}$. Complex $\left[\mathrm{NBu}_{4}\right]-1$ displays similar reactivity to the previously reported heterobimetallic complex, [Cs $\left.\left.\left\{\left({ }^{t} \mathrm{BuO}\right)_{3} \mathrm{SiO}\right)_{3} \cup\right\}_{2}(\mu-\mathrm{N})\right]$, [Cs]-1, whereas the amide complexes 2 and 4 are unreactive with these substrates. The mixed-ligand complexes 3 and 5 react with $\mathrm{CO}$ and $\mathrm{CO}_{2}$ but not $\mathrm{H}_{2}$. The nitride complexes $\left[\mathrm{NBu}_{4}\right]-1,2,4$, and 5 along with their small molecule activation products were structurally characterized. Magnetic data measured for the all-siloxide complexes [ $\left.\mathrm{NBu}_{4}\right]-1$ and $[\mathrm{Cs}]-1$ show uncoupled uranium centers, while strong antiferromagnetic coupling was found in complexes containing amide ligands, namely 2 and 5 (with maxima in the $\chi$ versus $T$ plot of $90 \mathrm{~K}$ and $55 \mathrm{~K}$ ). Computational analysis indicates that the $U(\mu-N)$ bond order decreases with the introduction of oxygen-based ligands effectively increasing the nucleophilicity of the bridging nitride.
\end{abstract}

\section{Introduction}

Uranium nitride compounds are of high interest because of their recently discovered ability to promote the stoichiometric transformation of small molecules such as $\mathrm{CO}_{2}, \mathrm{CO}$ and $\mathrm{N}_{2},{ }^{1}$ which are widely available $\mathrm{C} 1$ and $\mathrm{N}$ feedstocks for the synthesis of high-value organic compounds. ${ }^{2}$ Notably, examples of small molecule activation by nitride compounds remain scarce ${ }^{3}$ both in d-block $^{4}$ and in f-block chemistry. Moreover, uranium nitrides are driving experimental and computational studies because they are well suited to probe the nature of bonding in actinide compounds $\mathrm{s}^{5,6}$ and to promote magnetic communication between uranium centers in various oxidation states. ${ }^{1,7}$

${ }^{a}$ Institut des Sciences et Ingénierie Chimiques, Ecole Polytechnique Fédérale de Lausanne (EPFL), 1015 Lausanne, Switzerland. E-mail: marinella.mazzanti@epfl.ch ${ }^{b}$ Laboratory for Quantum Magnetism, Institute of Physics, Ecole Polytechnique Fédérale de Lausanne (EPFL), CH-1015 Lausanne, Switzerland

$\dagger$ Electronic supplementary information (ESI) available: Synthetic methods, NMR spectra, crystallographic data, computational details. CCDC 1913257-1913264. For ESI and crystallographic data in CIF or other electronic format see DOI: $10.1039 / \mathrm{c} 9 \mathrm{sc} 02149 \mathrm{c}$
The number of isolated terminal and bridging uranium nitrides continues to increase, ${ }^{1 a, 1 e, 1,1,1, i, 5 b-5 d, 7 b, 8}$ but their synthesis remains far from trivial in part because of their high reactivity that may result in solvent deprotonation, $\mathrm{C}-\mathrm{H}$ activation ${ }^{8,9}$ or $\mathrm{C}-\mathrm{O}$ cleavage $\mathrm{e}^{1 d}$ of the ancillary ligand to afford amido or imido complexes. Moreover, studies of the reactivity of uranium nitrides have so far been limited to three ligand systems, ${ }^{1 c, 1 d, 1 f: 1 i}$ namely, complexes of the tris(tertbutoxy)siloxide ligand $\mathrm{OSi}\left(\mathrm{O}^{t} \mathrm{Bu}\right)_{3}$, the $\mathrm{U}^{5+}-\mathrm{U}^{5+}$ nitride $\left[\left(\mathrm{U}(\mathrm{N}[t-\mathrm{Bu}] \mathrm{Ar})_{3}\right)_{2}(\mu-\mathrm{N})\right]\left[\mathrm{B}\left(\mathrm{Ar}^{\mathrm{F}}\right)_{4}\right]$ with amide ligands, and lastly terminal nitrides supported by the tripodal tris-amido ligand $\operatorname{Tren}^{\mathrm{TIPS}}\left(\operatorname{Tren}^{\mathrm{TIPS}}=\mathrm{N}\left(\mathrm{CH}_{2} \mathrm{CH}_{2^{-}}\right.\right.$ $\left.\mathrm{NSi}^{\mathrm{i}} \mathrm{Pr}_{3}\right)_{3}$ ). The nitride in complexes of the siloxide and $\operatorname{Tren}^{\mathrm{TIPS}}$ ligands acts as a strong nucleophile and reacts with $\mathrm{CO}_{2}, \mathrm{CO}$,
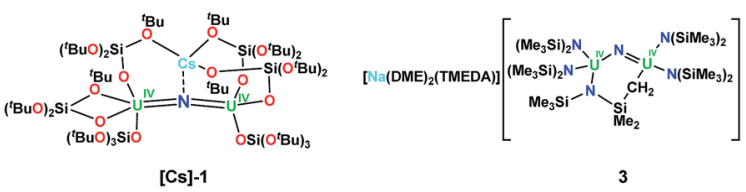

Chart 1 Previously characterized diuranium (U(IV)) nitride-bridged complexes supported by silylamide and siloxide ligands. 
and $\mathrm{CS}_{2}$ to give products of $\mathrm{N}-\mathrm{C}$ bond formation. ${ }^{1 c, 1 d, 1 f-1 i}$ The siloxide supported complexes also effect the cleavage of $\mathrm{H}_{2}$ leading to $\mathrm{N}-\mathrm{H}$ formation. ${ }^{1, \boldsymbol{c}, \boldsymbol{d a}, 1 \mathrm{f} \cdot \mathbf{1 i}}$ In contrast, the aforementioned $\left[\left(\mathrm{U}(\mathrm{N}[t-\mathrm{Bu}] \mathrm{Ar})_{3}\right)_{2}(\mu-\mathrm{N})\right]\left[\mathrm{B}\left(\mathrm{Ar}^{\mathrm{F}}\right)_{4}\right]$ was reported unreactive with $\mathrm{CO}$ but showed electrophilic reactivity towards cyanide resulting in the formation of a cyanoimide bridged $\mathrm{U}^{4+}-\mathrm{U}^{4+}$ complex. ${ }^{5 c}$

The geometric and electronic parameters leading to the observed differences in reactivity remain unclear. Moreover, the effects of the inner-sphere cation on the reactivity of the siloxide supported complex $\left[\mathrm{Cs}\left\{(\mathrm{LO})_{3} \mathrm{U}\right\}_{2}(\mu-\mathrm{N})\right]\left(\mathrm{LO}=\left({ }^{t} \mathrm{BuO}\right)_{3} \mathrm{SiO}\right),[\mathrm{Cs}]-\mathbf{1}$ (Chart 1), ${ }^{\mathrm{gg}, 1 b}$ was not elucidated. It occurred to us that the bulky silylamide ligand $\left(\mathrm{LN}=\mathrm{N}\left(\mathrm{SiMe}_{3}\right)_{2}\right)$ is well suited for determining ligand effects on the reactivity and magnetic properties of bridging nitrides because it is more electron-donating than the siloxide ligand LO with only a slightly higher steric demand. ${ }^{10}$ Earlier room temperature studies from the Hayton group $^{8 f}$ with the LN ligand led to the synthesis of the methylenebridged $\mathrm{U}^{4+}-\mathrm{U}^{4+}$ nitride complex $\left[\mathrm{Na}(\mathrm{dme})_{3}\right]\left[(\mathrm{LN})_{2} \mathrm{U}(\mu-\mathrm{N})\left(\mu-\kappa^{2}-\right.\right.$ $\mathrm{C}, \mathrm{N}-\mathrm{CH}_{2} \mathrm{SiMe}_{2} \mathrm{NSiMe}_{3}$ )-U(LN) ${ }_{2}$ ( dme = 1,2-dimethoxyethane), 3 (Chart 1).

Here we report the synthesis of three new diuranium $\mathrm{U}^{4+}-\mathrm{U}^{4+}$ nitride complexes, namely the all siloxide $\left[\mathrm{NBu}_{4}\right]\left[\left\{(\mathrm{LO})_{3} \mathrm{U}\right\}_{2}(\mu-\right.$ $\mathrm{N})],\left[\mathrm{NBu}_{4}\right]-1$, the all-amide $\left[\mathrm{NBu}_{4}\right]\left[\left\{(\mathrm{LN})_{3} \mathrm{U}\right\}_{2}(\mu-\mathrm{N})\right] \quad(\mathrm{LN}=$ $\left.\mathrm{N}\left(\mathrm{SiMe}_{3}\right)_{2}\right), \quad 2$, and the mixed-ligand $\left[\mathrm{Na}(\mathrm{dme})_{3}\right]\left[\left\{(\mathrm{LN})_{3} \mathrm{U}\right\}\right.$ $\left.\left\{(\mathrm{LO})(\mathrm{LN})_{2} \mathrm{U}\right\}(\mu-\mathrm{N})\right], \mathbf{5}$, which allow a straightforward analysis of the effects of cation and ancillary ligand on nitride reactivity. Comparative reactivity studies with small molecules, $\mathrm{CO}, \mathrm{CO}_{2}$, and $\mathrm{H}_{2}$ showed dramatic differences between the nitride complexes depending on the supporting ligands. No reactivity was shown by the all-amide complex 2 , but high nucleophilic reactivity of the nitride was observed with $\mathrm{CO}, \mathrm{CO}_{2}$, and $\mathrm{H}_{2}$ for the all-siloxide complex $\left[\mathbf{N B u}_{4}\right]-\mathbf{1}$. Moreover, the presence of only one siloxide ligand out of six supporting ligands is sufficient to enable $\mathrm{CO}, \mathrm{CO}_{2}$ activation by complex 5 . Computational studies inferred that the different behavior can be interpreted in terms of differences in the $\mathrm{U}=\mathrm{N}=\mathrm{U}$ bonding between the allsiloxide and the all-silylamide ligand. The increased orbital overlap between the $\mathrm{U}=\mathrm{N}=\mathrm{U}$ centers found in the allsilylamide complex results in stronger magnetic coupling between the two uranium centers and reduced nucleophilic character of the bridging nitride compared to the all-siloxide one.

\section{Results and discussion}

\section{Preparation of the nitride complexes}

The $\mathrm{U}(\mathrm{III})$ complexes $\left[\mathrm{U}(\mathrm{LN})_{3}\right]^{11}$ and $\left[\mathrm{U}(\mathrm{LO})_{2}(\mu-\mathrm{LO})\right]_{2}$ (ref. 12) react with $\mathrm{NBu}_{4} \mathrm{~N}_{3}$ to produce $\left[\mathrm{NBu}_{4}\right]\left[\left\{(\mathrm{LN})_{3} \mathrm{U}\right\}_{2}(\mu-\mathrm{N})\right](\mathrm{L}=\mathrm{LO}=$ $\left.\mathrm{OSi}\left(\mathrm{O}^{t} \mathrm{Bu}\right)_{3},\left[\mathrm{NBu}_{4}\right]-\mathbf{1} ; \mathrm{L}=\mathrm{LN}=\mathrm{N}\left(\mathrm{SiMe}_{3}\right)_{2}, 2\right)$, Scheme 1.

Compound $\left[\mathbf{N B u}_{4}\right]-\mathbf{1}$ is obtained in $70 \%$ yield using a method similar to that used to prepare the previously reported Cs analogue $[\mathrm{Cs}]-\mathbf{1}^{\mathrm{sg}}$ in which reduction of azide by $\left[\mathrm{U}(\mathrm{LO})_{2}(\mathrm{LO})\right]_{2}$ in thf is done at low temperature $\left(-40{ }^{\circ} \mathrm{C}\right)$. Single-crystals of $\left[\mathrm{NBu}_{4}\right]$-1 were obtained after storage of an $8: 1$ toluene/hexane solution at $-40{ }^{\circ} \mathrm{C}$. The ${ }^{1} \mathrm{H}$ NMR spectrum of $\left[\mathbf{N B u}_{4}\right]-\mathbf{1}$ shows resonances for the $\mathrm{NBu}_{4}{ }^{+}$cation and a single resonance for the

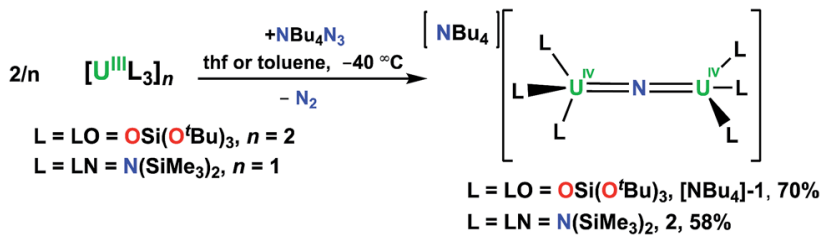

Scheme 1 Synthesis of $\left[\mathrm{NBu}_{4}\right]\left[\left\{(\mathrm{L})_{3} U\right\}_{2}(\mu-N)\right]\left(L=L O=O S i\left(O^{t} B u\right)_{3}\right.$, $\left.\left[\mathrm{NBu}_{4}\right]-1 ; \mathrm{L}=\mathrm{LN}=\mathrm{N}\left(\mathrm{SiMe}_{3}\right)_{2}, 2\right)$.

$\mathrm{OSi}\left(\mathrm{O}^{t} \mathrm{Bu}\right)_{3}$ in thf- $d_{8}$ and in toluene- $d_{8}$, indicating fluxional behavior of the siloxide ligands. Similar fluxional behavior had been observed for [Cs]-1 both in thf and toluene solution. Complex 2 can also be synthesized in thf, but in toluene precipitates as a brown powder in $58 \%$ yield. On several occasions while investigating the low temperature synthesis of 2 in toluene- $d_{8}$, single crystals of 2 grew in the NMR tube, which allowed its structural characterization. The ${ }^{1} \mathrm{H}$ NMR spectrum of 2 at $-60{ }^{\circ} \mathrm{C}$ in thf- $d_{8}$ shows two narrow and four broad resonances attributed to the $\mathrm{SiMe}_{3}$ groups, suggesting a rigid structure under these conditions. As the temperature is elevated to room temperature, the resonances become increasingly broadened until they are indistinguishable from the baseline; at room temperature, only those of the $\left[\mathrm{NBu}_{4}\right]^{+}$cation are observed.

Previously, it was shown that [Cs]-1 decomposes slowly at room temperature and more rapidly at $80{ }^{\circ} \mathrm{C}$ to afford the tertbutyl imide complex, $\quad\left[\mathrm{Cs}\left\{(\mathrm{LO})_{3} \mathrm{U}\left(\mu-\mathrm{N}^{t} \mathrm{Bu}\right)\left(\mu-\mathrm{O}_{2} \mathrm{Si}\left(\mathrm{O}^{t} \mathrm{Bu}\right)_{2}\right)\right.\right.$ $\left.\left.\mathrm{U}(\mathrm{LO})_{2}\right\}\right]{ }^{1 d}$ due to the high nucleophilic character of the bridging nitride in [Cs]-1. Monitoring the ${ }^{1} \mathrm{H}$ NMR spectrum of $\left[\mathrm{NBu}_{4}\right]-\mathbf{1}$ at room temperature or at $80^{\circ} \mathrm{C}$ demonstrates that its thermal stability is similar to that of [Cs]-1, but an imide product could not be identified in the decomposition mixture.

${ }^{1} \mathrm{H}$ NMR studies showed that $\mathbf{2}$ decomposes slowly (over six days) at room temperature and more rapidly at $65^{\circ} \mathrm{C}(2 \mathrm{~h})$ in thf$d_{8}$ to afford a mixture of species. Among the products, the proton resonances of the cyclometalate uranium nitride anion, $\left[(\mathrm{LN})_{2} \mathrm{U}(\mu-\mathrm{N})\left(\mu-\kappa^{2}-\mathrm{C}, \mathrm{N}-\mathrm{CH}_{2} \mathrm{SiMe}_{2} \mathrm{NSiMe}_{3}\right) \mathrm{U}(\mathrm{LN})_{2}\right]^{-}$, were identified. ${ }^{8 f}$ Thus, a $\mathrm{NBu}_{4}{ }^{+}$analogue of the $\mathrm{U}(\mathrm{Iv})$ nitride bridged complex $\quad\left[\mathrm{Na}(\mathrm{dme})_{3}\right]\left[(\mathrm{LN})_{2} \mathrm{U}(\mu-\mathrm{N})\left(\mu-\kappa^{2}-\mathrm{C}, \mathrm{N}-\mathrm{CH}_{2} \mathrm{SiMe}_{2} \mathrm{NSiMe}_{3}\right)\right.$ $\left.\mathrm{U}(\mathrm{LN})_{2}\right]$ (dme $=1,2$-dimethoxyethane), 3, reported previously by Hayton and coworkers, ${ }^{8 f}$ is formed during the decomposition. These results indicate that the cyclometallation side-reaction observed by Hayton and coworkers during the reaction of the $\left[\mathrm{U}(\mathrm{LN})_{3}\right]$ precursor with azide is prevented when the reaction is performed at low temperature.

In order to investigate the effect of the uranium oxidation state on the spectroscopic features and reactivity of the $\mathrm{N}\left(\mathrm{SiMe}_{3}\right)_{2}$ nitride complexes, a $\mathrm{U}^{4+}-\mathrm{U}^{5+}$ analogue of 2 , namely $\left[\left\{(\mathrm{LN})_{3} \mathrm{U}\right\}_{2}(\mu-\mathrm{N})\right], \mathbf{4}$, was also prepared. Complex 4 was obtained in $60 \%$ yield by oxidation of 2 with 1 equiv. of $\mathrm{AgBPh}_{4}$, Scheme 2. The ${ }^{1} \mathrm{H}$ NMR spectrum of $\mathbf{4}$ is similar to that of $\mathbf{2}$ in that it consists of two narrow and four broad resonances at $-60{ }^{\circ} \mathrm{C}$ and at room temperature, the resonances broaden and become indistinguishable from the baseline. Single crystals of 4 characterizable by X-ray crystallography were 

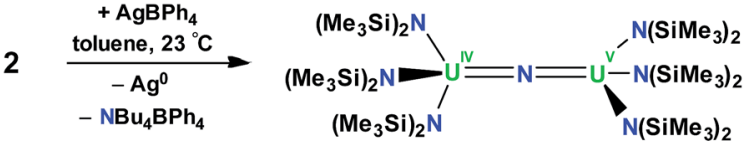

4

Scheme 2 Synthesis of $\left[\left\{(L N)_{3} U\right\}_{2}(\mu-N)\right], 4$

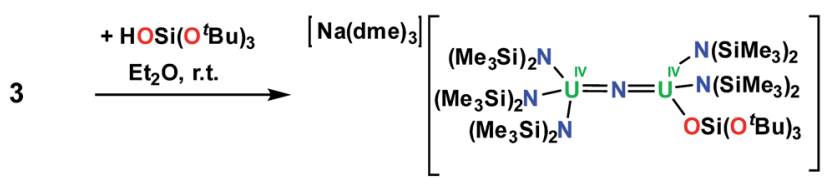

5

Scheme 3 Synthesis of $\left[\mathrm{Na}(\mathrm{dme})_{3}\right]\left[(\mathrm{LN})_{3} \mathrm{U}(\mu-\mathrm{N}) \cup(\mathrm{LN})_{2} \mathrm{LO}\right], 5$.

obtained by cooling a concentrated toluene solution to $-40{ }^{\circ} \mathrm{C}$.

In order to probe further ligand effects on reactivity and bonding, the synthesis of $\mathrm{OSi}\left(\mathrm{O}^{t} \mathrm{Bu}\right)_{3} / \mathrm{N}\left(\mathrm{SiMe}_{3}\right)_{2}$ mixed-ligand uranium nitride complexes was pursued. We first explored protonolysis reactions and attempted to synthesize $\left[\mathbf{N B u}_{\mathbf{4}}\right]-\mathbf{1}$ by reacting 2 with 6 equiv. of $\mathrm{HOSi}\left(\mathrm{O}^{t} \mathrm{Bu}\right)_{3}$, but ${ }^{1} \mathrm{H}$ NMR spectroscopy indicated that no reaction occurred between these two reagents at room temperature. This suggests that the $\mathrm{U}-\mathrm{N}$ bonds in complex 2 are significantly more resistant to protonolysis compared to those in the $\mathrm{U}(\mathrm{III})$ complex $\left[\mathrm{U}(\mathrm{LN})_{3}\right]^{11}$ that reacts rapidly with $\mathrm{HOSi}\left(\mathrm{O}^{t} \mathrm{Bu}\right)_{3}$ to afford the protonolysis product $\left[\mathrm{U}(\mathrm{LO})_{2}(\mu-\mathrm{LO})\right]_{2} \cdot{ }^{12}$

However, the cyclometalate $\mathrm{U}^{4+}$ nitride complex, $\left[\mathrm{Na}(\mathrm{dme})_{3}\right]$ $\left[(\mathrm{LN})_{2} \mathrm{U}(\mu-\mathrm{N})\left(\mu-\kappa^{2}-\mathrm{C}, \mathrm{N}-\mathrm{CH}_{2} \mathrm{SiMe}_{2} \mathrm{NSiMe}_{3}\right) \mathrm{U}(\mathrm{LN})_{2}\right], \quad 3,{ }^{8 f}$ reacts immediately with $\mathrm{HOSi}\left(\mathrm{O}^{t} \mathrm{Bu}\right)_{3}$, affording a mixed-ligand nitride of $\mathrm{N}\left(\mathrm{SiMe}_{3}\right)_{2}$ and $\mathrm{OSi}\left(\mathrm{O}^{t} \mathrm{Bu}\right)_{3}$ in $70 \%$ yield, $\left[\mathrm{Na}(\mathrm{dme})_{3}\right]\left[(\mathrm{LN})_{3} \mathrm{U}(\mu-\right.$ $\left.\mathrm{N}) \mathrm{U}(\mathrm{LN})_{2}(\mathrm{LO})\right], 5$, Scheme 3 . The room temperature ${ }^{1} \mathrm{H}$ NMR spectrum of 5 in thf- $d_{8}$ displays three resonances; two resonances at $1.08 \mathrm{ppm}$ and $-0.02 \mathrm{ppm}$ are attributed to the
$\mathrm{N}\left(\mathrm{SiMe}_{3}\right)_{2}$ ligands and another broad resonance at $-5.40 \mathrm{ppm}$ has been assigned to $\mathrm{OSi}\left(\mathrm{O}^{t} \mathrm{Bu}\right)_{3}$. Single crystals of 5 were grown by diffusion of hexane into an $\mathrm{Et}_{2} \mathrm{O}$ solution of 5 in the presence of dme.

\section{Structural characterization of the nitride-bridged complexes}

The solid-state structures of complexes [ $\left.\mathbf{N B u}_{4}\right]-\mathbf{1}, \mathbf{2}, \mathbf{4}$ and $\mathbf{5}$ were determined by X-ray diffraction studies. The metrical parameters are presented in Table 1, including those previously reported for complex $[\mathbf{C s}]-\mathbf{1}^{8 g}$ and $\left[\mathbf{N a}(\mathbf{d m e})_{2}\right.$ (tmeda)]-3 (ref. 8f) for comparison. The molecular structure of 4 (Fig. S39†) and a discussion of the metrical parameters of 4 are presented in the ESI. $\dagger$

Complex $\left[\mathbf{N B u}_{4}\right]-\mathbf{1}$ crystallizes in the $I 2$ space group and its molecular structure (Fig. 1) shows the presence of a $\mathrm{U}^{4+}-\mathrm{U}^{4+}$ complex bridged by a nitride ligand. In the solid-state structure of $\left[\mathbf{N B u}_{4}\right]-\mathbf{1}$, the $\mathrm{U}^{4+}$ ions of $\left[\mathrm{NBu}_{4}\right]-\mathbf{1}$ are disordered between two positions that were refined with $50 \%$ occupancy. Analysis of the X-ray data of $\left[\mathbf{N B u}_{4}\right]-\mathbf{1}$ reveals significant differences in the overall structure with respect to the previously reported [Cs]-1, but the disorder of the $\mathrm{U}-\mathrm{N}-\mathrm{U}$ core is such that its parameters are not reliable. In $\left[\mathbf{N B u}_{\mathbf{4}}\right]-\mathbf{1}$, each $\mathrm{U}(\mathrm{Iv})$ ion is four-coordinate and in a pseudo tetrahedral coordination environment bound by three $\kappa^{1}-\mathrm{OSi}\left(\mathrm{O}^{t} \mathrm{Bu}\right)_{3}$ ligands and one $\mu$-nitride ligand, which bridges the two $\left[(\mathrm{LO})_{3} \mathrm{U}\right]^{+}$units. The $\mathrm{OSi}\left(\mathrm{O}^{t} \mathrm{Bu}\right)_{3}$ ligands are in a staggered orientation with respect to those of the adjacent $\left[(\mathrm{LO})_{3} \mathrm{U}\right]^{+}$moiety as reflected in the $6(2)^{\circ}$ twist angle. In the previously reported ${ }^{8 g}$ structure of [Cs]-1, the binding situation is more complicated. There are one $\kappa^{1}-\mathrm{OSi}\left(\mathrm{O}^{t} \mathrm{Bu}\right)_{3}$, one $\kappa^{2}$ $\mathrm{OSi}\left(\mathrm{O}^{t} \mathrm{Bu}\right)_{3}$, and four $\mu-\kappa^{2}-\mathrm{O}, \mathrm{O}^{t \mathrm{Bu}}-\mathrm{OSi}\left(\mathrm{O}^{t} \mathrm{Bu}\right)_{3}$ ligands which bridge $\mathrm{U}(\mathrm{Iv})$ and $\mathrm{Cs}^{+}$cations. The inner-sphere $\mathrm{Cs}^{+}$is located at the apical position of the nitride ligand. The metal-siloxide bond distances/angles are very similar in $\left[\mathbf{N B u}_{4}\right]-\mathbf{1}$ and [Cs]-1. The disorder in the uranium atoms gives three distinct $\mathrm{U}-\mathrm{N}-\mathrm{U}$ angles $\left(\mathrm{U} 1 \mathrm{~A}-\mathrm{N}-\mathrm{U} 1 \mathrm{~A}=177(1)^{\circ}, \mathrm{U} 1 \mathrm{~B}-\mathrm{N}-\mathrm{U} 1 \mathrm{~B}=174(1)^{\circ}\right.$ and U1A$\left.\mathrm{N}-\mathrm{U} 1 \mathrm{~B}=172.2(2)^{\circ}\right)$ and suggests many possibilities of $\mathrm{U}-\mathrm{N}-\mathrm{U}$ angle in the solid state. This could indicate the presence of two molecules with a $\mathrm{U}=\mathrm{N}=\mathrm{U}$ angle of $172.2(2)^{\circ}$ or four molecules

Table 1 Selected bond lengths $(\AA)$ and angles $\left(^{\circ}\right)$ of the previously reported $\left[C s\left\{(L O)_{3} U\right\}_{2}(\mu-N)\right],[C s]-1,{ }^{8 g}$ along with $\left.\left[N B u_{4}\right]\left[\{(L O))_{3} U\right\}_{2}(\mu-N)\right]$, $\left[\mathrm{NBu}_{4}\right]-1,\left[\mathrm{Na}(\mathrm{dme})_{3}\right]\left[(\mathrm{LN})_{3} \cup(\mu-\mathrm{N}) \cup(\mathrm{LN})_{2}(\mathrm{LO})\right], 5,\left[\mathrm{NBu}_{4}\right]\left[\left\{(\mathrm{LN})_{3} \mathrm{U}\right\}_{2}(\mu-\mathrm{N})\right], 2$, and $\left[\left\{(\mathrm{LN})_{3} \mathrm{U}\right\}_{2}(\mu-\mathrm{N})\right]$, 4, ordered by the number of amide ligands. Complex $\left[\mathrm{Na}(\mathrm{dme})_{2}\right.$ (tmeda) $]-3$ was also added for comparison

\begin{tabular}{|c|c|c|c|c|c|c|}
\hline Complex & {$[\mathrm{Cs}]-1$} & {$\left[\mathrm{NBu}_{4}\right]-\mathbf{- 1}$} & 5 & $\begin{array}{l}{\left[\mathrm{Na}(\text { dme })_{2}(\text { tmeda })\right]-} \\
3 \\
(\text { ref. } 8 f)\end{array}$ & 2 & 4 \\
\hline $\mathrm{U}-$ & $2.19(1)$ & $2.2(1)$ & $2.208(4)$ & - & - & - \\
\hline$\left(\mathrm{O}_{\text {siloxide }}\right)_{\text {avg }}$ & & & & & & \\
\hline Twist angle ${ }^{b}$ & $24(11)$ & $6(2)$ & $15(1)$ & - & $1.7(4)$ & $18(1)$ \\
\hline
\end{tabular}




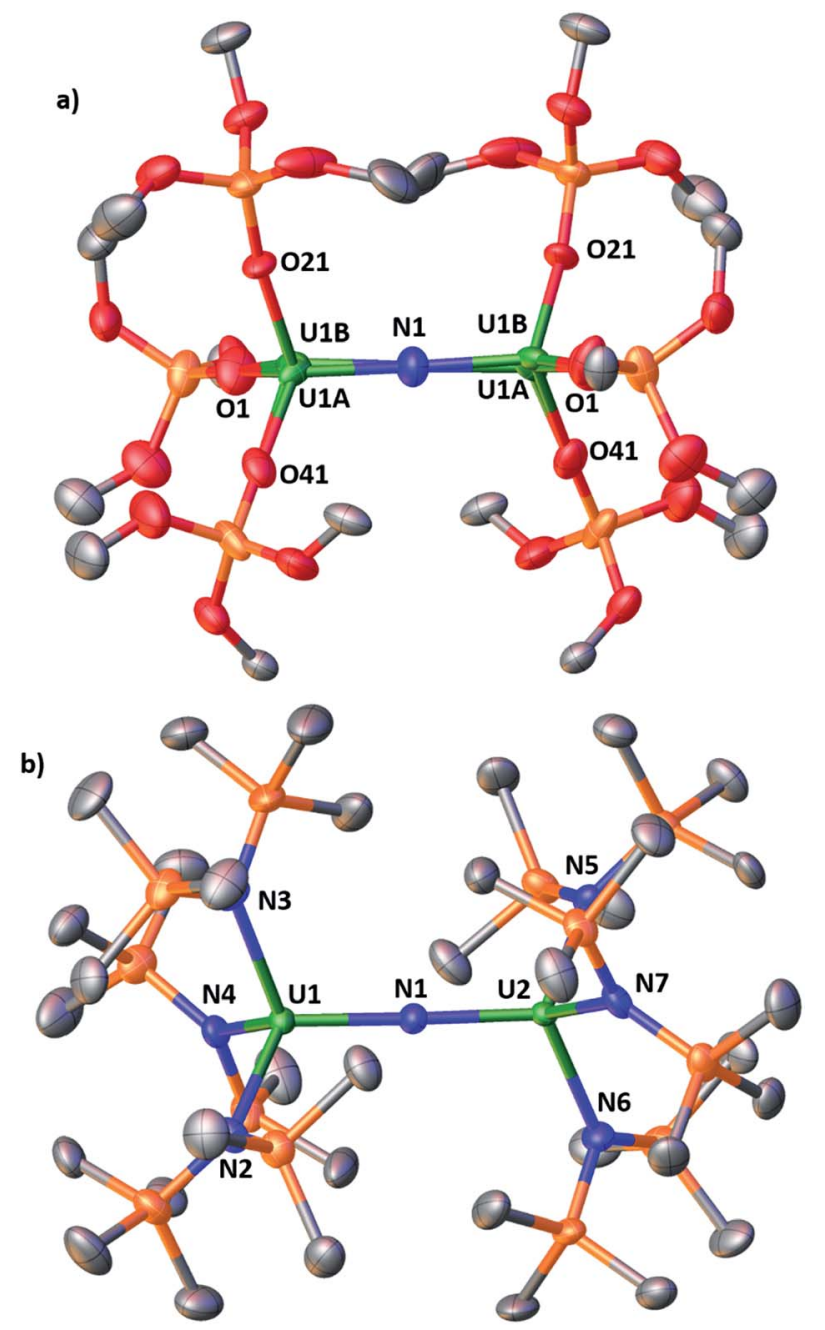

Fig. 1 Molecular structure of (a) $\left[\mathrm{NBu}_{4}\right]\left[\left\{(\mathrm{LO})_{3} \mathrm{U}\right\}_{2}(\mu-\mathrm{N})\right]$, $\left[\mathrm{NBu}_{4}\right]-1$, and (b) $\left[\mathrm{NBu}_{4}\right]\left[\left\{(\mathrm{LN})_{3} \cup\right\}_{2}(\mu-\mathrm{N})\right]$, 2, with thermal ellipsoids drawn at the $50 \%$ probability level. Hydrogen atoms, the methyl groups of the tert-butyl moieties and the $\mathrm{NBu}_{4}{ }^{+}$cation have been omitted for clarity.

with different $\mathrm{U}=\mathrm{N}=\mathrm{U}$ angles (two at $172.2(2)^{\circ}$, one at $177(1)^{\circ}$, and one at $\left.174(1)^{\circ}\right)$.

The structure of the $\left[\left\{(\mathrm{LN})_{3} \mathrm{U}\right\}_{2}(\mu-\mathrm{N})\right]^{-}$anion (Fig. 1b) in 2 shows the presence of a dinuclear U(Iv) complex with two $\left[(\mathrm{LN})_{3} \mathrm{U}\right]^{+}$units bridged by a nitride ligand. The coordination geometry of each four-coordinate uranium ion is pseudo tetrahedral and the arrangement of the $\mathrm{N}\left(\mathrm{SiMe}_{3}\right)_{2}$ ligands in the two $\left[\left((\mathrm{LN})_{3} \mathrm{U}\right]^{+}\right.$units is staggered as reflected by the $1.7(4)^{\circ}$ twist angle. The $178.7(2)^{\circ}$ and $180.0^{\circ} \mathrm{U}-\mathrm{N}-\mathrm{U}$ angles found in 2 are larger than that found in the siloxide complex Cs-1 and are very close to linearity. For comparison, the angle in the previously reported $\left[\mathrm{NBu}_{4}\right]\left[\left\{\left(\left(3,5-\mathrm{Me}_{2} \mathrm{C}_{6} \mathrm{H}_{3}\right)\left({ }^{t} \mathrm{Bu}\right) \mathrm{N}\right)_{3} \mathrm{U}\right\}_{2}(\mu-\mathrm{N})\right]^{5 c}$ complex containing the $\left(3,5-\mathrm{Me}_{2} \mathrm{C}_{6} \mathrm{H}_{3}\right)\left({ }^{t} \mathrm{Bu}\right) \mathrm{N}$ amido ligand is $175.1(2)^{\circ}$. The other metrical parameters in $\left[\mathrm{NBu}_{4}\right]\left[\left\{\left(\left(3,5-\mathrm{Me}_{2} \mathrm{C}_{6} \mathrm{H}_{3}\right)\left({ }^{t} \mathrm{Bu}\right)\right.\right.\right.$ $\left.\mathrm{N})_{3} \mathrm{U}_{2}(\mu-\mathrm{N})\right]$ are similar to 2 (see Table S2 in the ESI $\dagger$ ), but changes between the $\mathrm{U}^{4+}-\mathrm{U}^{4+}$ and $\mathrm{U}^{4+}-\mathrm{U}^{5+}$ complexes differ in the two classes of compounds. The $\mathrm{U}-\mathrm{N}_{\text {nitride }}$ distances in the $\mathrm{U}^{4+}-\mathrm{U}^{5+}$ compound 4 are different suggesting the presence of localized valence. A detailed structural comparison of $\mathbf{2}$ and $\mathbf{4}$

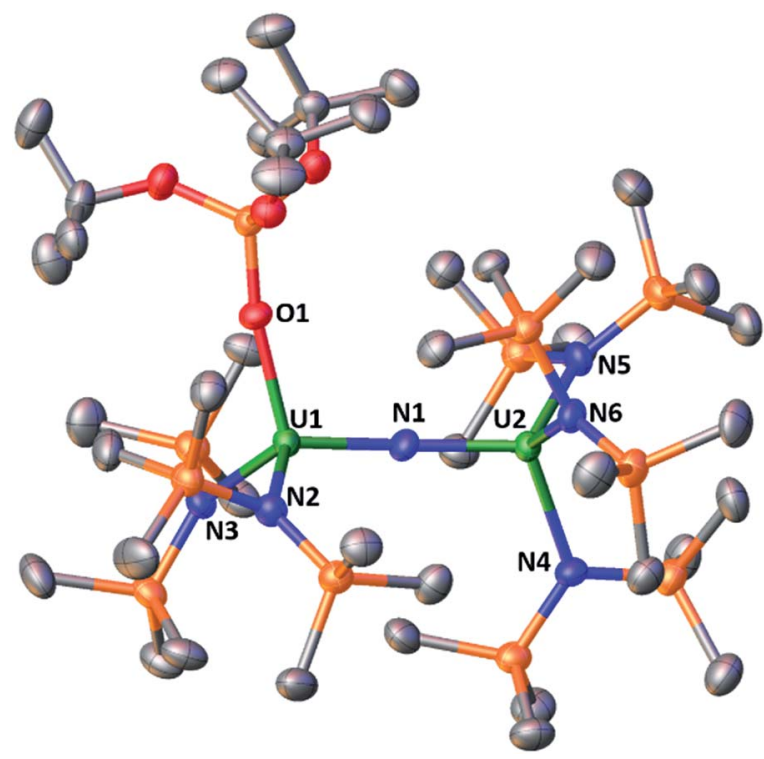

Fig. 2 Molecular structure of $\left[\mathrm{Na}(\mathrm{dme})_{3}\right]\left[(\mathrm{LN})_{3} \cup(\mu-\mathrm{N}) \cup(\mathrm{LN})_{2} L \mathrm{LO}, 5\right.$, with thermal ellipsoids drawn at the $50 \%$ probability level. Hydrogen atoms and a $\left[\mathrm{Na}(\mathrm{dme})_{3}\right]^{+}$cation are omitted for clarity.

with $\left[\mathrm{NBu}_{4}\right]\left[\left\{\left(\left(3,5-\mathrm{Me}_{2} \mathrm{C}_{6} \mathrm{H}_{3}\right)\left({ }^{t} \mathrm{Bu}\right) \mathrm{N}\right)_{3} \mathrm{U}\right\}_{2}(\mu-\mathrm{N})\right]$ and $\left[\left\{\left(\left(3,5-\mathrm{Me}_{2}-\right.\right.\right.\right.$ $\left.\left.\left.\mathrm{C}_{6} \mathrm{H}_{3}\right)\left({ }^{t} \mathrm{Bu}\right) \mathrm{N}\right)_{3} \mathrm{U}_{2}(\mu-\mathrm{N})\right]$ is presented in the ESI. $\dagger$

The molecular structure of the mixed-ligand complex 5 shows a dinuclear nitride-bridged U(Iv) complex with an outer sphere cation, $\left[\mathrm{Na}(\mathrm{dme})_{3}\right]^{+}$, (Fig. 2). The $\left[(\mathrm{LN})_{2}(\mathrm{LO}) \mathrm{U}(\mu-\mathrm{N})\right.$ $\left.\mathrm{U}(\mathrm{LN})_{3}\right]^{-}$anion shows two different ligand environments for the two U(Iv) centers; one $\mathrm{U}(\mathrm{Iv})$ is bound by two $\mathrm{N}\left(\mathrm{SiMe}_{3}\right)_{2}$ amide ligands and one $\kappa^{1}-\mathrm{OSi}\left(\mathrm{O}^{t} \mathrm{Bu}\right)_{3}$ siloxide ligand while the second $\mathrm{U}(\mathrm{Iv})$ is ligated by three amides. Both $\mathrm{U}(\mathrm{Iv})$ ions are fourcoordinate in a pseudotetrahedral coordination environment and the ligands are gauche with respect to those of the adjacent $\mathrm{U}(\mathrm{Iv})$ ion. A comparison of the structure of 5 with those of [Cs]-1 and 2 shows they have similar $\mathrm{U}-\mathrm{N}_{\text {nitride }}$ and $\mathrm{U}-\mathrm{O}_{\text {siloxide }}$ and $\mathrm{U}-$ $\mathrm{N}_{\text {amide }}$ bond distances. Interestingly, the presence of only one siloxide ligand results in a significant deviation of the $\mathrm{U}-\mathrm{N}-\mathrm{U}$ angle from linearity. The value of the $\mathrm{U}-\mathrm{N}-\mathrm{U}$ angle in $\mathbf{5}$ $\left(168.4(3)^{\circ}\right)$ is close to that found in Cs-1 $\left(170.3(3)^{\circ}\right)$ containing six siloxide ligands. These structural data indicate that the ligands significantly affect the solid-state metrical parameters of the $\mathrm{U}=\mathrm{N}=\mathrm{U}$ core.

We assessed the small molecule reactivity of the complexes to explore the effect of ancillary ligands on the reactivity.

\section{Small molecule reactivity}

The reactivity of the newly prepared nitride-bridged complexes with $\mathrm{CO}, \mathrm{CO}_{2}$, and $\mathrm{H}_{2}$ was investigated and compared with that of [Cs]-1 $\mathbf{1}^{1 b-1 d, 1 h}$ with the objective of relating differences in reactivity to structure. The reactivity of $5-10 \mathrm{mM}$ solutions of the complexes was monitored by ${ }^{1} \mathrm{H}$ and ${ }^{13} \mathrm{C}$ NMR spectroscopies and X-ray crystallography when single crystals were obtainable. The NMR spectra and additional X-ray characterization data are presented in the ESI. $\dagger$ 
CO. The siloxide complexes $[\mathbf{C s}]-\mathbf{1}$ and $\left[\mathbf{N B u}_{\mathbf{4}}\right]-\mathbf{1}$ show immediate reactivity with 1-2 equiv. of CO. As previously reported, [Cs]1 reacts cleanly with $\mathrm{CO}$ in toluene- $d_{8}$ to afford the $\mu$-oxo cyanide complex, $\left[\mathrm{Cs}\left\{(\mathrm{LO})_{3} \mathrm{U}\right\}_{2}(\mu-\mathrm{CN})(\mu-\mathrm{O})\right]{ }^{1 c}$ When $[\mathrm{Cs}]-\mathbf{1}$ is reacted in thf$d_{8}$, the ${ }^{1} \mathrm{H}$ NMR spectrum of the reaction mixture is more complicated, but hydrolysis of the reaction residue with $\mathrm{pD}=12$ $\mathrm{D}_{2} \mathrm{O}$ and analysis by ${ }^{13} \mathrm{C}$ NMR spectroscopy indicates that ${ }^{13} \mathrm{CN}^{-}$ is also produced under these conditions.

In our previous work, computational studies had pointed out the importance of cooperative binding of $\mathrm{CO}$ by the multimetallic U-N-Cs nitride fragment. Therefore, we investigated the reaction of the $\left[\mathbf{N B u}_{4}\right]-\mathbf{1}$ that does not contain a bound $\mathrm{Cs}^{+}$ cation. The reaction of $\left[\mathbf{N B u}_{4}\right]-\mathbf{1}$ with ${ }^{13} \mathrm{CO}$ in both toluene- $d_{8}$ and thf- $d_{8}$ also showed conversion of ${ }^{13} \mathrm{CO}$ to ${ }^{13} \mathrm{CN}^{-}$. In toluene$d_{8}$, the ${ }^{1} \mathrm{H}$ NMR spectrum of the reaction mixture is more complicated than for the $[\mathbf{C s}]-\mathbf{1}^{\mathbf{1 c}}$ case and, among the products, the resonances of the known $\mu$-oxo complex, $\left.\left[\left\{(\mathrm{LO})_{3} \mathrm{U}\right\}_{2}(\mu-\mathrm{O})\right]\right]^{7 a}$ and of the tetrakis(siloxide) complex, $\left[\mathrm{U}(\mathrm{LO})_{4}\right],{ }^{13}$ were identified, and indicated ligand scrambling reactions. The tetrakis(siloxide) product of ligand scrambling was observed for [Cs]-1 only in trace amounts or only after heating solutions of [Cs $\left.\left\{(\mathrm{LO})_{3} \mathrm{U}\right\}_{2}(\mu-\mathrm{CN})(\mu-\mathrm{O})\right]$ to $66^{\circ} \mathrm{C}$. The difference in behavior could be explained by an increased stability that the cesium cation provides to $\left[\mathrm{Cs}\left\{(\mathrm{LO})_{3} \mathrm{U}\right\}_{2}(\mu-\mathrm{CN})(\mu-\mathrm{O})\right]$. Notably, the inner sphere cesium cation binds four siloxide oxygen atoms and the bridging oxo, which could hold together the overall structure and prevent scrambling. In the thf- $d_{8}$ reaction of $\left[\mathbf{N B u}_{\mathbf{4}}\right]-\mathbf{1}$ with ${ }^{13} \mathrm{CO}$, only a single product was observed in the ${ }^{1} \mathrm{H}$ NMR spectrum that resonates at $2.66 \mathrm{ppm}$. In the ${ }^{13} \mathrm{C}$ spectrum of the reaction mixture in thf- $d_{8}$, we identified a resonance at $634.7 \mathrm{ppm}$, which we have assigned to a uranium bound ${ }^{13} \mathrm{CN}^{-}$ ligand. In both the toluene- $d_{8}$ and thf- $d_{8}$ reactions, when the reaction residue is hydrolysed with $\mathrm{pD}=12 \mathrm{D}_{2} \mathrm{O},{ }^{13} \mathrm{CN}^{-}$is observed as the only product by ${ }^{13} \mathrm{C}$ NMR spectroscopy. The spectra are shown in the ESI (Fig. S15-S19†).

A solution of the diuranium(Iv) amide complex 2 was monitored by ${ }^{1} \mathrm{H}$ NMR spectroscopy after exposure to 1 atm of CO. After $5 \mathrm{~h}$, only minor resonances consistent with decomposition were observed. The $\mathrm{U}^{4+}-\mathrm{U}^{5+}$ amide complex 4 also showed no reactivity when exposed to $1 \mathrm{~atm}$ of $\mathrm{CO}$.

The ${ }^{13} \mathrm{CO}$ reactivity of the mixed-ligand $\mathbf{5}$ was explored in thf$d_{8}$ (Fig. S23-S26†) but not in toluene- $d_{8}$ due to its insolubility. Complex 5 reacts with $1-2$ equiv. of ${ }^{13} \mathrm{CO}$, but more slowly than the [Cs]-1 and $\left[\mathbf{N B u}_{\mathbf{4}}\right]-\mathbf{1}$ complexes. Full consumption of $\mathbf{5}$ was observed only after $c a .24 \mathrm{~h}$ and the ${ }^{1} \mathrm{H}$ NMR spectrum appeared complicated. Analysis of the reaction mixture by ${ }^{13} \mathrm{C}$ NMR spectroscopy in thf- $d_{8}$ did not allow an assignment of a resonance for a bound ${ }^{13} \mathrm{CN}^{-}$ligand. However, after removal of the volatiles and hydrolysis with $\mathrm{pD}=12 \mathrm{D}_{2} \mathrm{O},{ }^{13} \mathrm{CN}^{-}$was identified by ${ }^{13} \mathrm{C}$ NMR spectroscopy. Attempts to grow single crystals from reactions with 1-2 equiv. of natural isotope abundance $\mathrm{CO}$ produced only amorphous powders.

To test whether a $\mathrm{U}(\mathrm{Iv})$ nitride complex without a $\mathrm{OSi}\left(\mathrm{O}^{t} \mathrm{Bu}\right)_{3}$ ligand would react with CO, we examined 3 (Fig. S20-S22†). We report only its reactivity in thf- $d_{8}$ due to its limited solubility in toluene- $d_{8}$. The ${ }^{1} \mathrm{H}$ NMR spectra in thf- $d_{8}$ from reactions of 3 with either 1 atm of $\mathrm{CO}$ or $1-2$ equiv. of ${ }^{13} \mathrm{CO}$ appear identical (see Fig. S24 and S25 in the ESI $\dagger$ ) suggesting that the product distribution is not affected by the stoichiometry of CO. In the 1-2 equiv. of ${ }^{13} \mathrm{CO}$ reaction, complete consumption of 3 was observed after $c a$. 9 h. Similar to the 5 result, we did not identify a resonance attributable to a bound ${ }^{13} \mathrm{CN}^{-}$ligand in the thf- $d_{8}{ }^{13} \mathrm{C}$ NMR spectrum, but did observe ${ }^{13} \mathrm{CN}^{-}$when the reaction residue was hydrolysed with $\mathrm{pD}=12 \mathrm{D}_{2} \mathrm{O}$. From the reactions of 3 with 1 atm of CO, crystals of several U(IV) oxo products were characterized by X-ray crystallography, namely the trimeric bis(amide) oxo, $\left[(\mathrm{LN})_{2} \mathrm{U}(\mathrm{O})\right]_{3}, 6$, and an oxo product where $\mathrm{CO}$ had inserted into the uranium-methylene bond, $\left[(\mathrm{LN})_{2} \mathrm{U}(\mu-\mathrm{O}) \mathrm{U}\left(\mu-\kappa^{2}-\mathrm{O}, \mathrm{N}-\mathrm{OC}(=\mathrm{C}) \mathrm{SiMe}_{2} \mathrm{NSiMe}_{3}\right) \mathrm{U}(\mathrm{LN})_{2}\right]$, 7, Fig. 3 (see ESI $\dagger$ for structural description). The products obtained from the reaction of 3 with 1 atm of $\mathrm{CO}$ are illustrated in Scheme 4.

The CO insertion chemistry has been observed previously in mononuclear uranium(Iv) metallacycles, ${ }^{\mathbf{1 4}}$ but these results demonstrate its extension to uranium nitride complexes.

a)
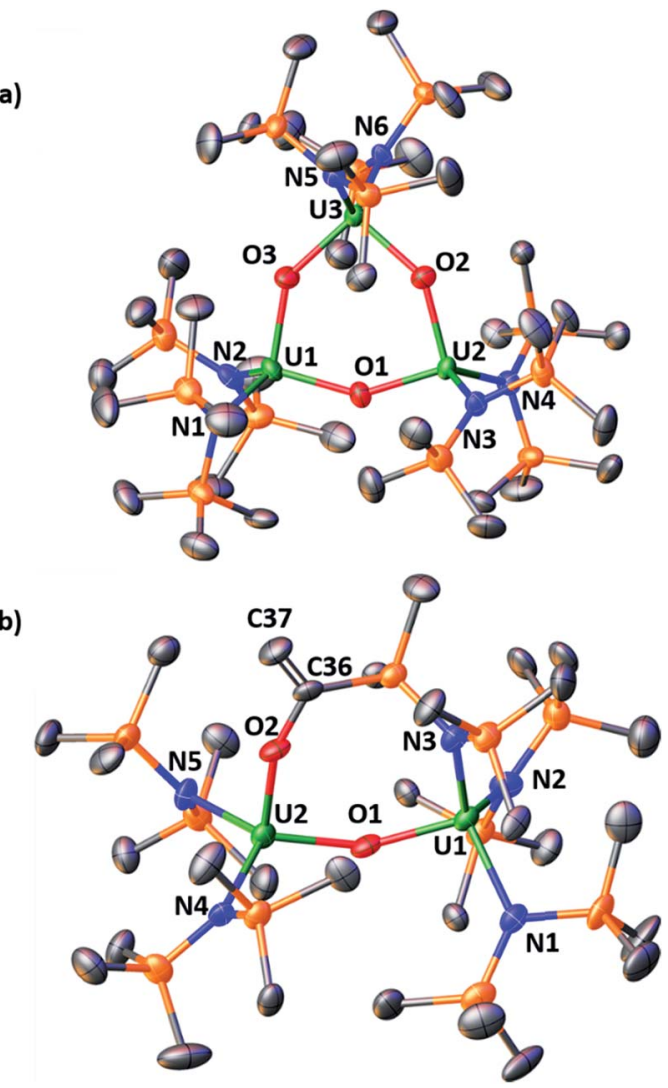

Fig. 3 Molecular structure of (a) $\left[(L N)_{2} \cup(O)\right]_{3}, 6$, and (b) $\left[(L N)_{2} \cup(\mu-O)\right.$ $\left.\mathrm{U}\left(\mu-\kappa^{2}-\mathrm{O}, \mathrm{N}-\mathrm{OC}(=\mathrm{C}) \mathrm{SiMe}_{2} \mathrm{NSiMe} \mathrm{S}_{3}\right) \mathrm{U}(\mathrm{LN})_{2}\right]$, 7, with thermal ellipsoids drawn at the $50 \%$ probability level. Hydrogen atoms have been omitted for clarity. The asymmetric unit contains 2 independent molecules. Only 1 is shown for sake of clarity. Selected bond lengths and angles of $\left[(\mathrm{LN})_{2} \mathrm{U}(\mathrm{O})\right]_{3}: \mathrm{U}-\left(\mathrm{N}_{\text {amide }}\right)_{\text {avg }}, 2.28(1) \AA ; \mathrm{U}-\left(\mathrm{O}_{\text {oxo }}\right)_{\text {avg, }}$ 2.10(2) $\AA$; U-O-U, $144(1)^{\circ}$. Selected bond lengths and angles of $\left[(L N)_{2} \cup(\mu-O) \cup\left(\mu-\kappa^{2}-O, N-\right.\right.$ $\left.\left.\mathrm{OC}(=\mathrm{C}) \mathrm{SiMe}_{2} \mathrm{NSiMe}_{3}\right) \mathrm{U}(\mathrm{LN})_{2}\right]: \mathrm{U} 1-\left(\mathrm{N}_{\text {amide }}\right)_{\text {avg }}, 2.27(4) \AA ; \mathrm{U} 2-\left(\mathrm{N}_{\text {amide }}\right)-$

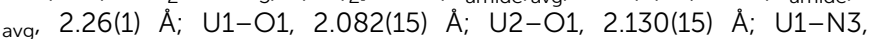
2.256(16) $\AA$; U2-O2, 2.074(13) Å; C36-C37, 1.32(3); U1-O1-U2, 150.3(7). 

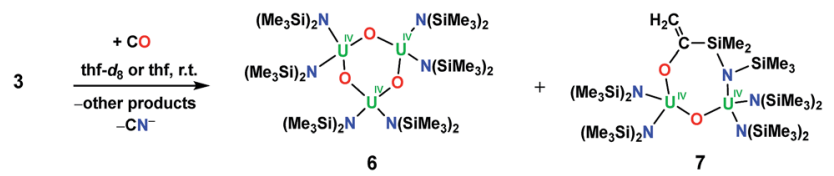

Scheme 4 Reaction of $\left[\mathrm{Na}(\mathrm{dme})_{3}\right]\left[(\mathrm{LN})_{2} \mathrm{U}(\mu-\mathrm{N})\left(\mu-\kappa^{2}-\mathrm{C}, \mathrm{N}-\mathrm{CH}_{2} \mathrm{SiMe}_{2}-\right.\right.$ $\left.\left.\mathrm{NSiMe}_{3}\right) \cup(\mathrm{LN})_{2}\right]$, 3, with $\mathrm{CO}$.

The reactivity of the all-siloxide complexes [Cs]-1 and [ $\left.\mathbf{N B u}_{4}\right]-$ 1, which effect the cleavage of CO under ambient conditions, differs significantly from that of the all-amide complexes $\mathbf{2}$ and 4, which do not react with $\mathrm{CO}$ despite differences in their oxidation states. The $\mathrm{CO}$ cleavage reactivity is reinstated in the mixed ligand amide siloxide $\mathbf{5}$ and methanide $\mathbf{3}$ complexes, although in the case of 3 , CO insertion into the U-C bond also occurs concomitantly with $\mathrm{CO}$ cleavage. These results suggest reduced nucleophilic character of the nitride in the all-amide complexes compared to those with siloxide or methanide ligands.

$\mathbf{C O}_{2}$. Previously, our group reported the reaction of [Cs]-1 with 2-3 equiv. of $\mathrm{CO}_{2}$ in toluene, which produced the first example of a metal dicarbamate species, $\left[\mathrm{Cs}\left\{(\mathrm{LO})_{3} \mathrm{U}\right\}_{2}(\mu-\right.$ $\left.\mathrm{NC}_{2} \mathrm{O}_{4}\right)$ ], from $\mathrm{CO}_{2}$ addition to a metal nitride. ${ }^{d d}$ We found that under analogous conditions, $\left[\mathbf{N B u}_{4}\right]-\mathbf{1}$ reacts similarly with $\mathrm{CO}_{2}$ to afford the dicarbamate complex, $\left[\mathrm{NBu}_{4}\right]\left[\left\{(\mathrm{LO})_{3} \mathrm{U}\right\}_{2}\left(\mu-\mathrm{NC}_{2} \mathrm{O}_{4}\right)\right]$, $\mathbf{8}$, Scheme 5. Single crystals of $\mathbf{8}$ characterizable by X-ray diffraction were grown from a 9:1 toluene/hexane mixture at $-40{ }^{\circ} \mathrm{C}$, Fig. 4 . The ${ }^{1} \mathrm{H}$ NMR spectrum generated from crystals of 8 in toluene- $d_{8}$ shows a broad resonance ranging $2-0 \mathrm{ppm}$ assigned to $\mathrm{OSi}\left(\mathrm{O}^{t} \mathrm{Bu}\right)_{3}$ of $\mathbf{8}$. The ${ }^{13} \mathrm{C}$ NMR spectrum in toluene$d_{8}$ shows a broad resonance at $141.5 \mathrm{ppm}$ assigned to the bound dicarbamate ligand. Hydrolysis of crystals of 8 with $\mathrm{pD}=12$ $\mathrm{D}_{2} \mathrm{O}$ and analysis by ${ }^{13} \mathrm{NMR}$ spectroscopy showed only $\mathrm{D}^{13} \mathrm{CO}_{3}{ }^{-}$. Similar results were obtained when the reaction was performed in thf and hydrolysis of the reaction residue similarly showed only $\mathrm{D}^{13} \mathrm{CO}_{3}{ }^{-}$, Fig. S30.†

The structure of the anion in $\mathbf{8}$ can be described as a dinuclear complex in which an asymmetric $\mu-\kappa^{2}-\mathrm{O}, \mathrm{O}-: \mathrm{\kappa}^{2}-\mathrm{O}, \mathrm{N}-$ $\mathrm{N}\left(\mathrm{CO}_{2}\right)_{2}{ }^{3-}$ dicarbamate ligand bridges two U(Iv) cations in two $\left[(\mathrm{LO})_{3} \mathrm{U}\right]^{+}$units. One uranium cation is bound by the nitrogen atom and a carboxylate oxygen atom, while the second one is bound by two oxygen atoms from the two different carboxylate units. The $\mathrm{U}_{2} \mathrm{NC}_{2} \mathrm{O}_{4}$ core comprises two fused rings, with one six membered ring (UOCNCO) and one four membered ring (UNCO) which share the $\mathrm{C}-\mathrm{N}$ bond and are coplanar. A similar binding mode is found for the Cs analogue $\left[\mathrm{Cs}\left\{(\mathrm{LO})_{3} \mathrm{U}\right\}_{2}(\mu-\right.$ $\left.\left.\mathrm{NC}_{2} \mathrm{O}_{4}\right)\right]^{1 d}$ except for the fact that the dicarbamate moiety also binds a Cs cation.

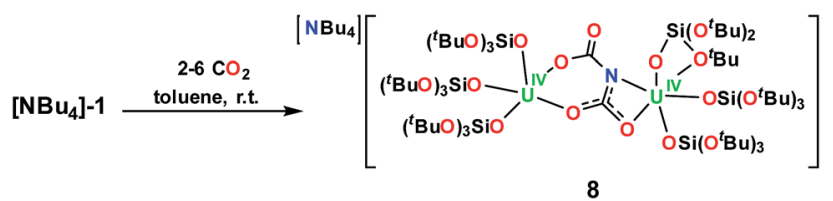

Scheme 5 Reaction of $\left[N B u_{4}\right]\left[\left\{(L O)_{3} \cup\right\}_{2}(\mu-N)\right]$, $\left[N B u_{4}\right]-1$, with $\mathrm{CO}_{2}$.

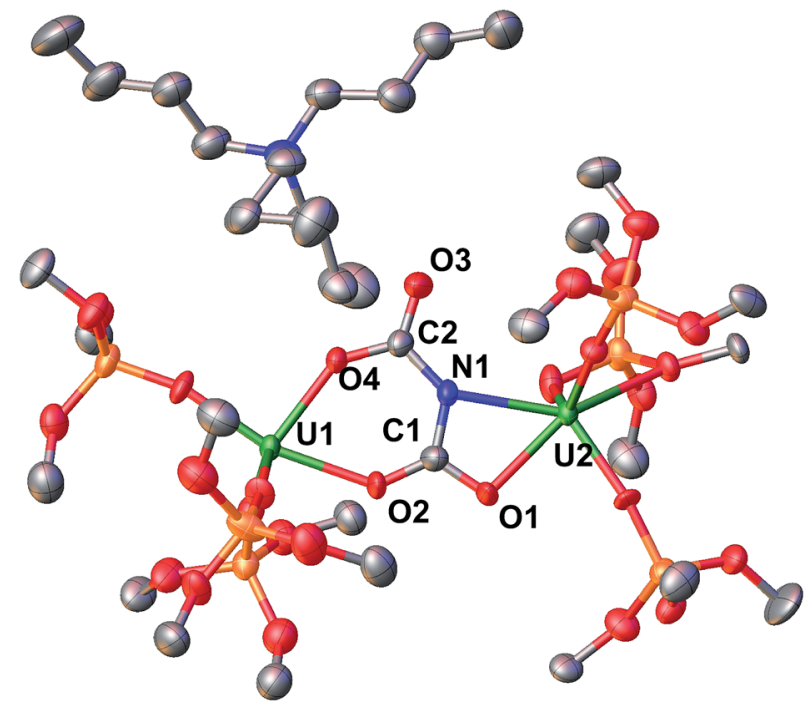

Fig. 4 Molecular structure of $\left[\mathrm{NBu}_{4}\right]\left[\left\{(\mathrm{LO})_{3} \mathrm{U}\right\}_{2}\left(\mu-\mathrm{NC}_{2} \mathrm{O}_{4}\right)\right]$, 8 with thermal ellipsoids drawn at the $50 \%$ probability level. Hydrogen atoms and the methyl groups of the tert-butyl moieties have been omitted for clarity. U1- $\left(\mathrm{O}_{\text {siloxide }}\right)_{\mathrm{avg}}=2.14(2) \AA, \mathrm{U} 2-\left(\mathrm{O}_{\text {siloxide }}\right)_{\mathrm{avg}}=2.13(2) \AA$, U1-O2 $=2.320(6) \AA, U 1-\mathrm{N} 1=2.460(7) \AA, U 2-\mathrm{O} 3=2.222(6) \AA, U 2-\mathrm{O} 1=$ $2.267(6) \AA, \mathrm{N} 1-\mathrm{C} 1=1.344(12) \AA, \mathrm{O} 2-\mathrm{C} 1=1.279(12) \AA, \mathrm{O} 1-\mathrm{C} 1=$ $1.285(12) \AA, \mathrm{O} 3-\mathrm{C} 2=1.323(11) \AA, \mathrm{O} 4-\mathrm{C} 2=1.225(12) \AA, \mathrm{N} 1-\mathrm{C} 1-\mathrm{O} 2=$ $112.7(1)^{\circ}$, torsion angles: $\mathrm{O} 2-\mathrm{C} 1-\mathrm{N} 1-\mathrm{C} 2=176.5(8)^{\circ}, \mathrm{O} 4-\mathrm{C} 2-\mathrm{N} 1-\mathrm{C} 1$ $=-174.5(9)^{\circ}$.

We explored the $\mathrm{CO}_{2}$ reactivity of the amide complexes 2 and 4 with $\mathrm{CO}_{2}$ but found that exposure of thf- $d_{8}$ solutions of these complexes to $1 \mathrm{~atm}$ of $\mathrm{CO}_{2}$ does not produce any change in their respective ${ }^{1} \mathrm{H}$ NMR spectra indicating no reactivity.

The bridging nitrides in the heteroleptic amide methanide, 3 , and amide siloxide, 5 , both react with 2 equiv. or $1 \mathrm{~atm} \mathrm{CO}_{2}$ in thf $-d_{8}$ to produce a complicated mixture of products. The products could not be isolated, but hydrolysis with $\mathrm{pD}=12 \mathrm{D}_{2} \mathrm{O}$ of the reaction residues after reactions of 3 or 5 with 2-6 equiv. ${ }^{13} \mathrm{CO}_{2}$ showed $\mathrm{N}^{13} \mathrm{CO}^{-}$as the only product originating of the nitride; evidence for a dicarbamate product was not obtained in either case. The formation of cyanate indicates that the reaction of 3 and 5 with excess $\mathrm{CO}_{2}$ proceeds with deoxygenation and $\mathrm{N}-\mathrm{C}$ bond formation. Similar reactivity leading to the formation of oxo cyanate complexes had been reported for [Cs]-1 at substoichiometric ratios of $\mathrm{CO}_{2}$ (ref. $1 d$ ) and for terminal $\mathrm{U}(\mathrm{v})$ nitrides. ${ }^{19}$

These results show that the replacement of one amide ligand (out of six ligands) by one siloxide is sufficient to promote nitride transfer to $\mathrm{CO}_{2}$. The different reactivity of $\mathbf{3}$ and $\mathbf{5}$ compared to $\left[\mathbf{N B u}_{4}\right]-\mathbf{1}$ indicates that bridging nitrides in complexes supported by amide ligands are less nucleophilic and react preferentially with one $\mathrm{CO}_{2}$ molecule with the rate of $\left(\mathrm{NCO}_{2}\right)^{3-}$ cleavage to yield $\mathrm{NCO}^{-}$and $\mathrm{O}^{2-}$ being faster than the addition of a second $\mathrm{CO}_{2}$ molecule. All of the spectra are shown in Fig. S27-S35 in the ESI. $\dagger$

$\mathbf{H}_{2}$. Examination of the $\mathrm{H}_{2}$ reactivity of the nitride complexes demonstrated reactivity only for $\left[\mathbf{N B u}_{4}\right]-\mathbf{1}$ (Fig. S36-S38†). [ $\left.\mathbf{N B u}_{4}\right]-\mathbf{1}$ reacts immediately with $\mathrm{H}_{2}$ yielding a yellow-green 
solution from which the $\mathrm{U}(\mathrm{Iv})$ imide hydride complex, $\left[\mathrm{NBu}_{4}\right]$ $\left[\left\{(\mathrm{LO})_{3} \mathrm{U}\right\}_{2}(\mu-\mathrm{NH})(\mu-\mathrm{H})\right]$, 9, was obtained in $69 \%$ yield after crystallization from a $1: 1$ toluene/hexane mixture, Scheme 6 (Fig. 5).

Complex 9 is the $\mathrm{NBu}_{4}{ }^{+}$analogue of the $\left[\mathrm{Cs}\left\{\mathrm{U}(\mathrm{LO})_{3}\right\}_{2}(\mu-\mathrm{H})(\mu-\right.$ $\mathrm{NH})$ complex previously obtained when [Cs]-1 was reacted with $\mathrm{H}_{2}$ under similar conditions. ${ }^{1 \boldsymbol{h}}$ The $\mathrm{NH}$ and $\mathrm{H}$ resonances of $\left[\mathrm{NBu}_{4}\right]\left[\left\{(\mathrm{LO})_{3} \mathrm{U}\right\}_{2}(\mu-\mathrm{NH})(\mu-\mathrm{H})\right]$ were identified at 188.1 and 720.2 ppm, respectively, in toluene- $d_{8}$. Consistent with this, when $\mathrm{D}_{2}$ is used the resonances are no longer observable. The $\left[\mathrm{NBu}_{4}\right]\left[\left\{(\mathrm{LO})_{3} \mathrm{U}_{2}(\mu-\mathrm{NH})(\mu-\mathrm{H})\right]\right.$ complex is stable to dynamic vacuum and shows no evidence of reversible binding of $\mathrm{H}_{2}$. In contrast, $\mathrm{H}_{2}$ addition to the [Cs]-1 complex was found to be reversible. ${ }^{1 h}$ The reversibility of $\mathrm{H}_{2}$ addition to $[\mathbf{C s}]-\mathbf{1}$ and the different behavior observed for $\left[\mathbf{N B u}_{\mathbf{4}}\right]-\mathbf{1}$ can be rationalized in the terms of the differences in the solid-state structures of the two imide hydride complexes. Complex 9 can be described as a dinuclear complex in which $\mu-\mathrm{NH}$ and a $\mu-\mathrm{H}$ ligands bridge two 5-coordinate $\mathrm{U}(\mathrm{Iv})$ ions bound as two $\left[(\mathrm{LO})_{3} \mathrm{U}\right]^{+}$units. The U-N bond distances (2.222(3) A and 2.209(3) A) are significantly longer than those found in the parent compound, $\left[\mathbf{N B u}_{\mathbf{4}}\right] \mathbf{- 1}$ (2.032(2) A and 2.067(2) $\mathrm{A}$ ), and are similar to those found in the imido bridged diuranium(Iv) complexes $\left[\mathrm{Cs}\left\{\mathrm{U}(\mathrm{LO})_{3}\right\}_{2}(\mu-\mathrm{H})(\mu-\right.$ $\mathrm{NH})],^{{ }^{\boldsymbol{h}}}(2.231(7) \AA$ and $2.288(8) \AA)$, and $\left[\mathrm{K}_{2}\left\{\left[\mathrm{U}(\mathrm{LO})_{3}\right]_{2}(\mu-\mathrm{NH})_{2}\right\}\right]$

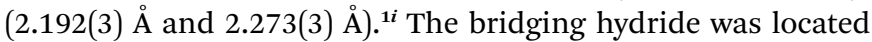
in the Fourier difference map and the U-H distances (2.31(4) $\AA$ and 2.23(4) $\AA$ ) are similar to those found in the Cs analogue (2.18(6) and 2.36(6) $\AA$ ) ${ }^{1 h}$ and those determined by neutron diffraction studies for the complex $\left[\mathrm{U}\left(\mathrm{C}_{5} \mathrm{Me}_{5}\right)_{2}(\mu-\mathrm{H})_{2}\right]_{2}$ of 2.134(9) $\AA .{ }^{15}$ In the cesium complex, the cesium cation lies at the apical position of the hydride ligand with a $\mathrm{Cs}-\mathrm{H}$ distance of 2.73(6) A. The $\mathrm{Cs}-\mathrm{H}$ interaction is probably rendering more labile the $\mathrm{U}-\mathrm{H}$ binding and facilitating the $\mathrm{H}_{2}$ elimination when the $\mathrm{H}_{2}$ headspace is removed. In contrast, the absence of the coordinated cesium cation evidently reduces its reactivity towards $\mathrm{H}_{2}$ elimination.

$\mathrm{H}_{2}$ cleavage was not observed for the heteroleptic complexes, 3 and 5, nor for the all-amide complexes $\mathbf{2}$ and $\mathbf{4}$ at ambient conditions. This can be explained in term of their reduced nucleophilic character.

Overall, the correlations between structural parameters and nucleophilic reactivity are not obvious except that the all-amide complexes with the linear $\mathrm{U}=\mathrm{N}=\mathrm{U}$ angle are the least reactive. The different reactivity with $\mathrm{H}_{2}$ of the mixed-ligand complex 5 and the all-siloxide complexes $\mathbf{1}$ suggests a reduced nucleophilicity of the nitride in complex $\mathbf{5}$ in spite of the presence of a bent $\mathrm{U}=\mathrm{N}=\mathrm{U}$ angle. This suggests that the nucleophilicity of

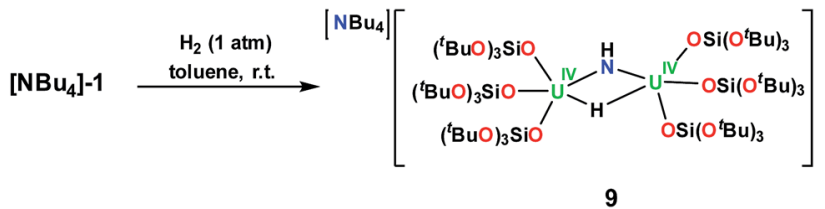

Scheme 6 Reaction of $\left[\mathrm{NBu}_{4}\right]\left[\left\{(\mathrm{LO})_{3} \mathrm{U}\right\}_{2}(\mu-\mathrm{NH})(\mu-\mathrm{H})\right]$ with $\mathrm{H}_{2}, 9$.

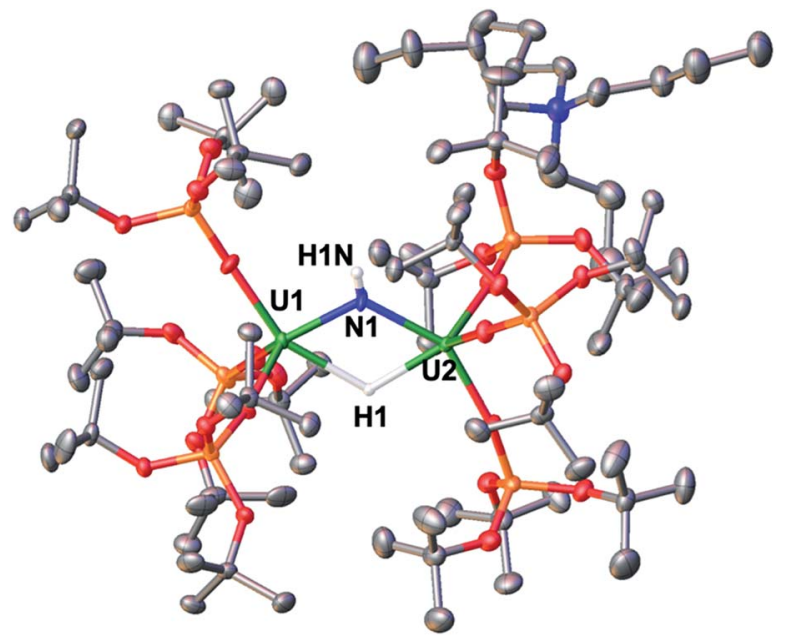

Fig. 5 Molecular structure of $\left[\mathrm{NBu}_{4}\right]\left[\left\{(\mathrm{LO})_{3} \mathrm{U}\right\}_{2}(\mu-\mathrm{NH})(\mu-\mathrm{H})\right]$, 9, with thermal ellipsoids drawn at the $50 \%$ probability level. Hydrogen atoms of the siloxide ligands, and a toluene molecule have been omitted for clarity. Selected structural parameters: $U-\left(O_{\text {siloxide }}\right)_{a v g}=2.17(1) \AA, U-$ $\mathrm{N}_{\mathrm{avg}}=2.216(2) \AA, \mathrm{U}-\mathrm{H}_{\mathrm{avg}}=2.27(3) \AA, \mathrm{U} 1-\mathrm{N} 1-\mathrm{U} 2=116.71(14)^{\circ}, \mathrm{U} 1-$ $\mathrm{H} 1-\mathrm{U} 2=113(2)^{\circ}$

the nitride is affected by ligand electronics which do not always result in obvious structural differences.

In order to further investigate how differences in bonding could explain the observed difference in reactivity we turned to other methods.

\section{Magnetic properties}

Magnetic communication between uranium centers can provide important information on the nature of bonding ${ }^{.5 b, 7 a, 8 f, 16}$ and lead to attractive magnetic properties. ${ }^{17}$ Examples of unambiguous magnetic coupling are rare in uranium chemistry and mostly limited to antiferromagnetic coupling between uranium(v) centers with values of $\chi$ maximum in the $\chi$ versus $T$ plots ranging from 5 to $77 \mathrm{~K}^{7 \boldsymbol{a}, \mathbf{1 6 b}, \mathbf{1 8}}$ Stronger antiferromagnetic coupling with the highest value of $\chi$ maximum at $110 \mathrm{~K}$ was reported by Cummins and Diaconescu for an arene-bridged $\mathrm{U}(\mathrm{III})$ dimer. $^{19}$ In contrast, two examples of unambiguous magnetic coupling between two U(IV) ions were reported for diuranium(IV) chalcogenide complexes with $\chi$ maxima at 3 and $20 \mathrm{~K}^{20}$ Strong antiferromagnetic coupling has been also suggested from the $\sim 60 \mathrm{~K}$ maximum in the $\chi$ versus $T$ plot of an amide supported nitride-bridged $\mathrm{U}^{4+}-\mathrm{U}^{4+}$ also presenting a linear $\mathrm{U}=\mathrm{N}=\mathrm{U}$ core, complex. $^{7 \boldsymbol{b}}$

The $\chi$ versus $T$ plot for complex 2 (Fig. 6) shows the magnetic behavior of an antiferromagnetically coupled dinuclear complex with a maximum in the $\chi$ versus $T$ plot of approximately $90 \mathrm{~K}$. Below $20 \mathrm{~K}$, an increase of the magnetic susceptibility is observed which we attribute to small amounts of paramagnetic impurities. Thus, the linear $\mathrm{U}(\mathrm{IV})=\mathrm{N}=\mathrm{U}(\mathrm{IV})$ unit in the all amide complex exhibits a strong coupling between the two $\mathrm{f}^{2}$ ions higher than for any other $\mathrm{U}^{4+}-\mathrm{U}^{4+}$ complex.

For the all-siloxide complexes $\left[\mathbf{N B u}_{\mathbf{4}}\right]-\mathbf{1}$ and [Cs]-1 (Fig. 6), and for the all-amide $\mathrm{U}^{4+}-\mathrm{U}^{5+}$ complex 4 (Fig. S43 $\dagger$ ), the $\chi$ versus 


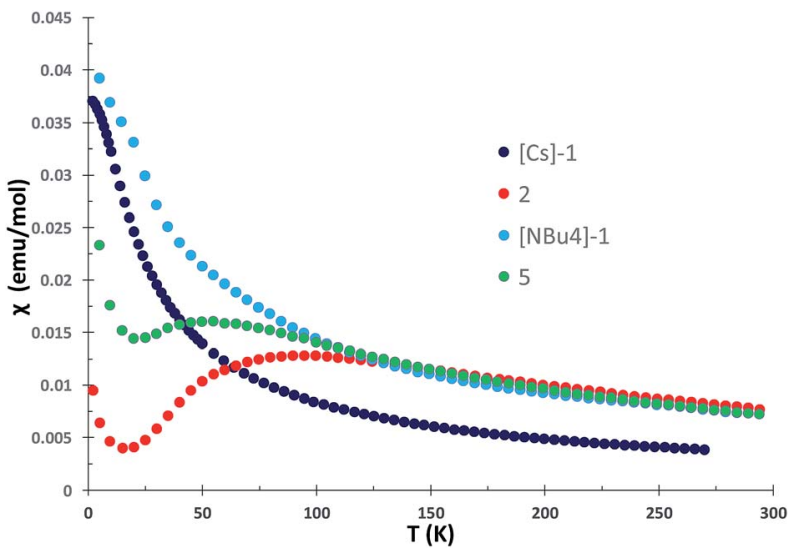

Fig. 6 Plot of $\chi$ versus temperature data for the all-siloxide complexes [Cs]-1 and [NBu 4$]-1$ and the all-amide complex 2 measured in $1 \mathrm{~T}$ field.

$T$ plot shows a continuous increase and for $\left[\mathbf{N B u}_{\mathbf{4}}\right] \mathbf{- 1}$ and $[\mathbf{C s}]-\mathbf{1}$ approaches a temperature-independent plateau at low temperature. This behavior is characteristic of magnetically isolated uranium ions in complexes. ${ }^{8 e, 18 f, 20 b, 21}$ A similar behavior was also reported for the amide methanide complex 3 , which was interpreted in terms of a localized $\mathrm{U}=\mathrm{N}$ bonding interactions of the bridging nitrido ligand (as suggested by the inequivalent $\mathrm{U}-$ $\mathrm{N}_{\text {nitride }}$ distances). ${ }^{8 f} \mathrm{~A}$ shorter U-U distance is found in the solidstate structure of the all-siloxide complexes $\left[\mathrm{NBu}_{4}\right]-\mathbf{1}(4.107(2) \AA)$ and Cs-1 (4.1214(4) $\mathrm{A})$ compared to the amide complex $2(4.15 \AA)$, but coupling is observed only in the amide complex. The $\chi$ versus $T$ plot for the mixed siloxide-amide complex 5 (Fig. 6) shows the magnetic behavior of an antiferromagnetically coupled $\mathrm{U}^{4+}-\mathrm{U}^{4+}$ complex with a maximum in the $\chi$ versus $\mathrm{T}$ at $55 \mathrm{~K}$, significantly lower than for the all-amide complex 2 . In this complex, the $\mathrm{U}-\mathrm{N}-\mathrm{U}$ angle $\left(168^{\circ}\right)$ is similar to what found in all siloxide complex [Cs]-1 suggesting that there is no a relation between this structural parameter and the magnetic properties. The dramatic difference in the magnetic properties of complexes 2 and $\mathbf{5}$ compared to complexes $\left[\mathbf{N B u}_{4}\right]-\mathbf{1}$ and $[\mathbf{C s}]-\mathbf{1}$ are likely to arise from the electronic properties of the supporting ligands, which evidently lead to increased orbital overlap between the nitride and the two uranium(Iv) centers in the amide supported complex, enhancing the electronic communication between the two uranium centers. Such communication is reduced when one amide out of six is replaced by one siloxide. This is in line with the reactivity the nitride ligand in complex $\mathbf{5}$ which is increased compared to the all-amide complexes, but still lower than for allsiloxide complexes. In order to assess more thoroughly the $\mathrm{U}-\mathrm{N}-\mathrm{U}$ bonding scheme, we have computed the electronic structures of the three complexes.

\section{Computational studies}

Depending on the arrangement of the two $5 f$ electrons on each $\mathrm{U}^{\mathrm{IV}}$ center, the synthesized complexes are characterized either by a quintet, triplet, or singlet ground-state. Computations on the all-siloxide $\mathbf{1}$, the all-amide $\mathbf{2}$ and the mixed-ligand $\mathbf{5}$ complexes for each of these spin-states were performed at the DFT level (B3LYP/Def2-SVP/Def-SDD and M06L(-D3)/Def2-SVP/
Def-SDD (see ESI $\dagger$ )). The two formally degenerate states (triplet and singlet) were treated within a broken-symmetry (BS) formalism, starting from a spin-flip ansatz from the nondegenerate high-spin quintet state. According to both density functionals, the all-amide is characterized by a singlet antiferromagnetic ground-state (exchange couplings: $J_{\mathrm{B} 3 \mathrm{LYP}}(\mathrm{UU})=$ $-15.02 \mathrm{~cm}^{-1}$ and $J_{\text {M06L }}(\mathrm{UU})=-50.15 \mathrm{~cm}^{-1}$ ), while the quintet state is the most stable for the all-siloxide. Assigning the multiplicity of the mixed-ligand compound is more delicate, since this compound is more sensitive to the choice of the density functional, which has to be able to capture simultaneously the asymmetry in the ligand environment between the two uranium centers and mimic the effects of state degeneracies (see ESI $\dagger$ ). This complex results in a quintet with M06L and in a singlet anti-ferromagnetic state (exchange coupling: $J_{\mathrm{B} 3 \mathrm{LY}}$ $(\mathrm{UU})=-9.44 \mathrm{~cm}^{-1}$ ) with B3LYP. Although the results with B3LYP are in line with experimental magnetic properties for all the complexes, the relatively small energy differences (see ESI $\dagger$ ) between spin-states has to be taken with care.

Beside the differences in magnetic properties, Mayer bond order (MBO) analysis ${ }^{22}$ on the three complexes reveals a correlation between the increased reactivity of the complexes and a decreased bond-order between the uranium centers and the bridging nitrogen, despite the relatively small magnitude of the bond-order differences (Fig. 7 top panel). An opposite trend is found when considering the bond order between the uranium centers and the non-bridging ligands, suggesting that the modulation of the reactivity is linked to the relative strength of the $\mathrm{O}-\mathrm{U}$
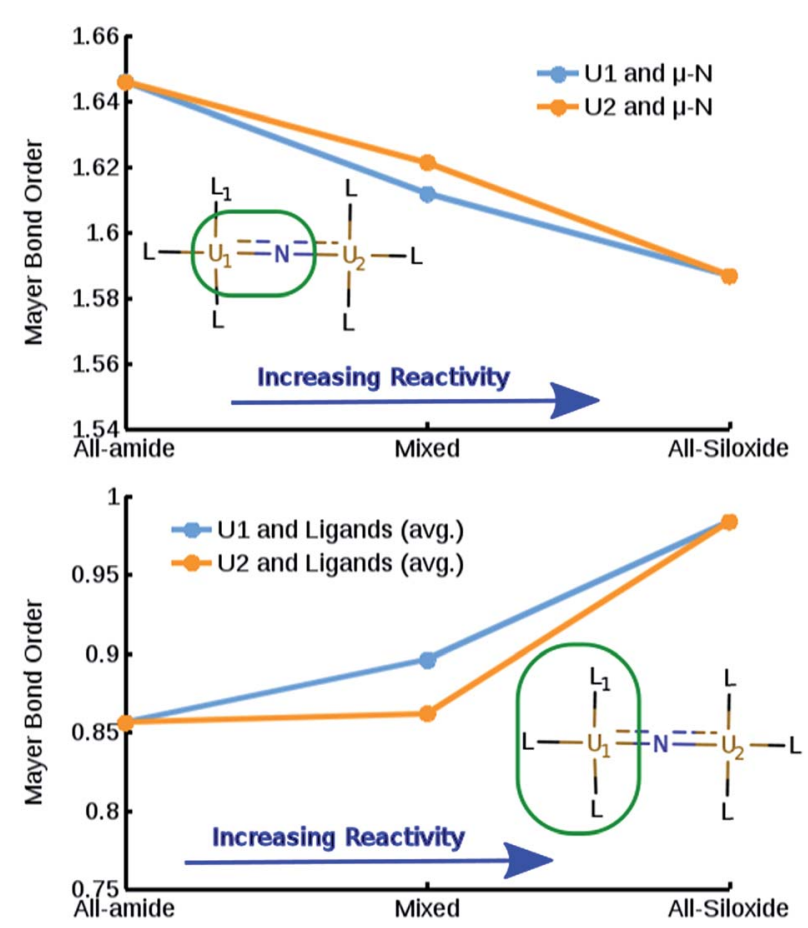

Fig. 7 (Top) Mayer Bond Order for $\mathrm{U}-\mathrm{N}$ bond in function of the complexes ordered per increasing reactivity. (Bottom) Mayer Bond Order between uranium centers and non-bridging ligands in function of the complexes ordered per increasing reactivity. $L_{1}$ indicates the position of the siloxide ligand in the mixed complex. 
bond, compared to the $\mathrm{N}-\mathrm{U}$ (Fig. 7 bottom panel). The overall reduced bond order between the bridging nitrogen and the uranium centers in the presence of oxygen-based ligands indicate an increased localization of the electron density on the bridging nitrogen and a consequent increase of its nucleophilic character.

\section{Conclusions}

In summary, four new examples of diuranium nitride bridged complexes have been prepared and structurally characterized, the siloxide supported $\left[\mathbf{N B u}_{\mathbf{4}}\right]-\mathbf{- 1}$, the amide supported $\mathbf{2}$ and $\mathbf{4}$, and the amide siloxide $\mathbf{5}$. The previously reported amide methanide complex $3^{8 f}$ demonstrated to be a useful precursor for the preparation of the mixed-ligand amide siloxide complex $\mathbf{5}$. The small molecule reactivity of the nitride group in the $\left[\mathrm{NBu}_{4}\right]-1,2,3$ and 5 has been investigated with $\mathrm{CO}, \mathrm{CO}_{2}$, and $\mathrm{H}_{2}$. Although [Cs]-1 and $\left[\mathrm{NBu}_{4}\right]-1$ show differences in structure, their reactivity is similar. Both complexes convert $\mathrm{CO}$ to $\mathrm{CN}^{-}$, react with $\mathrm{CO}_{2}$ to give dicarbamate $\left(\mathrm{N}\left(\mathrm{CO}_{2}\right)_{2}\right)^{3-}$, and react with $\mathrm{H}_{2}$ to yield imide hydride complexes. The only observed effect of the presence of an inner sphere cesium cation is that reversible $\mathrm{H}_{2}$ cleavage is observed in the $\mathrm{Cs}^{+}$case versus $\mathrm{NBu}_{4}^{+}$where it is irreversible.

The overall reactivity of the described nitride complexes can be summarized according to the ligand; the all-amide complexes 2 and 4 are unreactive with $\mathrm{CO}, \mathrm{CO}_{2}$, and $\mathrm{H}_{2}$ whereas the all-OSi $\left(\mathrm{O}^{t} \mathrm{Bu}\right)_{3}$ complexes 1 react with all of these substrates. The heteroleptic complexes 3 and 5 react with $\mathrm{CO}$ and $\mathrm{CO}_{2}$ but not $\mathrm{H}_{2}$. Complexes 1, 3, and 5 convert of $\mathrm{CO}$ to $\mathrm{CN}^{-}$ but their reactivity with $\mathrm{CO}_{2}$ is different; the all-OSi $\left(\mathrm{O}^{t} \mathrm{Bu}\right)_{3} 1$ convert $\mathrm{CO}_{2}$ to dicarbamate, whereas the mixed ligand complexes 3 and 5 favor $\mathrm{NCO}^{-}$formation. Finally, only the all$\mathrm{OSi}\left(\mathrm{O}^{t} \mathrm{Bu}\right)_{3}$ complexes 1 react with $\mathrm{H}_{2}$ and give imide/hydride complexes.

These results demonstrate that the all-OSi $\left(\mathrm{O}^{t} \mathrm{Bu}\right)_{3}$ ligand environment in $\mathrm{U}^{4+}-\mathrm{U}^{4+}$ nitride complexes allows reactivity that is not observed when amide ligands are used, (e.g., dicarbamate formation and reversible and irreversible $\mathrm{H}_{2}$ heterolysis), and highlights the unique chemistry that can be obtained in this coordination environment. The all-OSi $\left(\mathrm{O}^{t} \mathrm{Bu}\right)_{3}$ ligand environment provides nitrides that are highly nucleophilic and more reactive than those with amide ligands. In contrast, the allsilylamide ligand promotes magnetic exchange coupling but gives less reactive complexes. Computational analysis at the DFT level shows that increasing reactivity of the complexes correlates with a decrease in bond order of the bridging nitride, as well as with an increase in the bond order of the ancillary ligands.

\section{Conflicts of interest}

There are no conflicts to declare.

\section{Acknowledgements}

We acknowledge support from the Swiss National Science Foundation grant number 200021_162430, 200021_178793 and 200021_169699 and the Ecole Polytechnique Fédérale de
Lausanne (EPFL). We thank Dr Euro Solari for carrying out the elemental analyses, Farzaneh Fadaei-Tirani for important contributions to the X-ray single crystal structure analyses.

\section{Notes and references}

1 (a) M. Falcone, L. Chatelain, R. Scopelliti, I. Zivkovic and M. Mazzanti, Nature, 2017, 547, 332-335; (b) M. Falcone, L. Chatelain, R. Scopelliti and M. Mazzanti, Chimia, 2017, 71, 209-212; (c) M. Falcone, C. E. Kefalidis, R. Scopelliti, L. Maron and M. Mazzanti, Angew. Chem., Int. Ed. Engl., 2016, 55, 12290-12294; (d) M. Falcone, L. Chatelain and M. Mazzanti, Angew. Chem., Int. Ed. Engl., 2016, 55, 40744078; (e) D. M. King and S. T. Liddle, Coord. Chem. Rev., 2014, 266, 2-15; (f) P. A. Cleaves, D. M. King, C. E. Kefalidis, L. Maron, F. Tuna, E. J. L. McInnes, J. McMaster, W. Lewis, A. J. Blake and S. T. Liddle, Angew. Chem., Int. Ed. Engl., 2014, 53, 10412-10415; (g) P. A. Cleaves, C. E. Kefalidis, B. M. Gardner, F. Tuna, E. J. L. McInnes, W. Lewis, L. Maron and S. T. Liddle, Chem.-Eur. J., 2017, 23, 2950-2959; (h) M. Falcone, L. N. Poon, F. F. Tirani and M. Mazzanti, Angew. Chem., Int. Ed. Engl., 2018, 57, 3697-3700; (i) L. Barluzzi, L. Chatelain, F. Fadaei-Tirani, I. Zivkovic and M. Mazzanti, Chem. Sci., 2019, 10, 3543-3555.

2 (a) L. M. Duman and L. R. Sita, J. Am. Chem. Soc., 2017, 139, 17241-17244; (b) D. J. Knobloch, E. Lobkovsky and P. J. Chirik, J. Am. Chem. Soc., 2010, 132, 10553-10564; (c) M. Aresta, Carbon Dioxide as a Chemical Feedstock, Wiley $\mathrm{VCH}, 2010 ;(d)$ I. Klopsch, M. Kinauer, M. Finger, C. Wurtele and S. Schneider, Angew. Chem., Int. Ed. Engl., 2016, 55, 4786-4789; (e) A. J. Keane, W. S. Farrell, B. L. Yonke, P. Y. Zavalij and L. R. Sita, Angew. Chem., Int. Ed. Engl., 2015, 54, 10220-10224; (f) R. J. Burford and M. D. Fryzuk, Nat. Rev. Chem., 2017, 1, 0026.

3 (a) J. S. Silvia and C. C. Cummins, J. Am. Chem. Soc., 2009, 131, 446-447; (b) J. A. Buss, C. Cheng and T. Agapie, Angew. Chem., Int. Ed. Engl., 2018, 57, 9670-9674; (c) B. Askevold, J. T. Nieto, S. Tussupbayev, M. Diefenbach, E. Herdtweck, M. C. Holthausen and S. Schneider, Nat. Chem., 2011, 3, 532-537; (d) Y. Ishida and H. Kawaguchi, J. Am. Chem. Soc., 2014, 136, 16990-16993; (e) B. L. Tran, M. Pink, X. F. Gao, H. Park and D. J. Mindiola, J. Am. Chem. Soc., 2010, 132, 1458-1459; (f) J. J. Scepaniak, R. P. Bontchev, D. L. Johnson and J. M. Smith, Angew. Chem., Int. Ed. Engl., 2011, 50, 6630-6633; (g) S. D. Brown and J. C. Peters, J. Am. Chem. Soc., 2005, 127, 1913-1923; (h) A. F. Cozzolino, J. S. Silvia, N. Lopez and C. C. Cummins, J. Chem. Soc., Dalton Trans., 2014, 43, 4639-4652; ( $i$ ) J. K. Brask, V. Dura-Vila, P. L. Diaconescu and C. C. Cummins, Chem. Commun., 2002, 902-903; (j) J. S. Silvia and C. C. Cummins, J. Am. Chem. Soc., 2010, 132, 2169-2170; (k) S. P. Semproni and P. J. Chirik, Angew. Chem., Int. Ed. Engl., 2013, 52, 12965-12969; (l) S. P. Semproni and P. J. Chirik, J. Am. Chem. Soc., 2013, 135, 11373-11383. 
4 (a) J. M. Smith, Prog. Inorg. Chem., 2014, 58, 417-470; (b) R. A. Eikey and M. M. Abu-Omar, Coord. Chem. Rev., 2003, 243, 83-124.

5 (a) M. B. Jones and A. J. Gaunt, Chem. Rev., 2013, 113, 11371198; (b) D. M. King, P. A. Cleaves, A. J. Wooles, B. M. Gardner, N. F. Chilton, F. Tuna, W. Lewis, E. J. L. McInnes and S. T. Liddle, Nat. Commun., 2016, 7, 13773; (c) A. R. Fox, P. L. Arnold and C. C. Cummins, J. Am. Chem. Soc., 2010, 132, 3250-3251; (d) T. W. Hayton, Chem. Commun., 2013, 49, 2956-2973; (e) J. Su, E. R. Batista, K. S. Boland, S. E. Bone, J. A. Bradley, S. K. Cary, D. L. Clark, S. D. Conradson, A. S. Ditter, N. Kaltsoyannis, J. M. Keith, A. Kerridge, S. A. Kozimor, M. W. Loble, R. L. Martin, S. G. Minasian, V. Mocko, H. S. La Pierre, G. T. Seidler, D. K. Shuh, M. P. Wilkerson, L. E. Wolfsberg and P. Yang, J. Am. Chem. Soc., 2018, 140, 17977-17984; (f) E. Lu, S. Sajjad, V. E. J. Berryman, A. J. Wooles, N. Kaltsoyannis and S. T. Liddle, Nat. Commun., 2019, 10, 634.

6 (a) N. H. Anderson, S. O. Odoh, Y. Y. Yao, U. J. Williams, B. A. Schaefer, J. J. Kiernicki, A. J. Lewis, M. D. Goshert, P. E. Fanwick, E. J. Schelter, J. R. Walensky, L. Gagliardi and S. C. Bart, Nat. Chem., 2014, 6, 919-926; (b) N. Kaltsoyannis, Inorg. Chem., 2013, 52, 3407-3413.

7 (a) M. Falcone, L. Barluzzi, J. Andrez, F. F. Tirani, I. Zivkovic, A. Fabrizio, C. Corminboeuf, K. Severin and M. Mazzanti, Nat. Chem., 2019, 11, 154-160; (b) J. Du, D. M. King, L. Chatelain, E. Lu, F. Tuna, E. J. L. McInnes, A. J. Wooles, L. Maron and S. T. Liddle, Chem. Sci., 2019, 10, 3738-3745.

8 (a) A. R. Fox and C. C. Cummins, J. Am. Chem. Soc., 2009, 131, 5716-5717; (b) W. J. Evans, S. A. Kozimor and J. W. Ziller, Science, 2005, 309, 1835-1838; (c) I. Korobkov, S. Gambarotta and G. P. A. Yap, Angew. Chem., Int. Ed. Engl., 2002, 41, 3433-3436; (d) T. K. Todorova, L. Gagliardi, J. R. Walensky, K. A. Miller and W. J. Evans, J. Am. Chem. Soc., 2010, 132, 12397-12403; (e) G. Nocton, J. Pecaut and M. Mazzanti, Angew. Chem., Int. Ed. Engl., 2008, 47, 30403042; (f) S. Fortier, G. Wu and T. W. Hayton, J. Am. Chem. Soc., 2010, 132, 6888-6889; $(g)$ C. Camp, J. Pecaut and M. Mazzanti, J. Am. Chem. Soc., 2013, 135, 12101-12111; (h) L. Maria, I. C. Santos, V. R. Sousa and J. Marcalo, Inorg. Chem., 2015, 54, 9115-9126; (i) D. M. King, F. Tuna, E. J. L. McInnes, J. McMaster, W. Lewis, A. J. Blake and S. T. Liddle, Nat. Chem., 2013, 15, 482-488; (j) D. M. King, F. Tuna, E. J. L. McInnes, J. McMaster, W. Lewis, A. J. Blake and S. T. Liddle, Science, 2012, 337, 717-720; $(k)$ D. M. King, J. McMaster, F. Tuna, E. J. L. McInnes, W. Lewis, A. J. Blake and S. T. Liddle, J. Am. Chem. Soc., 2014, 136, 5619-5622; (l) L. Chatelain, R. Scopelliti and M. Mazzanti, J. Am. Chem. Soc., 2016, 138, 1784-1787; (m) N. Tsoureas, A. F. R. Kilpatrick, C. J. Inman and F. G. N. Cloke, Chem. Sci., 2016, 7, 4624-4632.

9 (a) R. K. Thomson, T. Cantat, B. L. Scott, D. E. Morris, E. R. Batista and J. L. Kiplinger, Nat. Chem., 2010, 2, 723729; (b) K. C. Mullane, H. Ryu, T. Cheisson, L. N. Grant, J. Y. Park, B. C. Manor, P. J. Carroll, M. H. Baik, D. J. Mindiola and E. J. Schelter, J. Am. Chem. Soc., 2018, 140, 11335-11340.
10 S. M. Mansell, J. H. Farnaby, A. I. Germeroth and P. L. Arnold, Organometallics, 2013, 32, 4214-4222.

11 (a) D. L. Clark, A. P. Sattelberger, S. G. Bott and R. N. Vrtis, Inorg. Chem., 1989, 28, 1771-1773; (b) J. L. Stewart and R. A. Andersen, Polyhedron, 1998, 17, 953-958.

12 V. Mougel, C. Camp, J. Pecaut, C. Coperet, L. Maron, C. E. Kefalidis and M. Mazzanti, Angew. Chem., Int. Ed. Engl., 2012, 51, 12280-12284.

13 O. Cooper, C. Camp, J. Pécaut, C. E. Kefalidis, L. Maron, S. Gambarelli and M. Mazzanti, J. Am. Chem. Soc., 2014, 136, 6716-6723.

14 (a) O. Benaud, J. C. Berthet, P. Thuery and M. Ephritikhine, Inorg. Chem., 2010, 49, 8117-8130; (b) S. J. Simpson and R. A. Andersen, J. Am. Chem. Soc., 1981, 103, 4063-4066; (c) P. L. Arnold, Z. R. Turner, A. I. Germeroth, I. J. Casely, G. S. Nichol, R. Bellabarba and R. P. Tooze, J. Chem. Soc., Dalton Trans., 2013, 42, 1333-1337.

15 D. Grant, T. J. Stewart, R. Bau, K. A. Miller, S. A. Mason, M. Gutmann, G. J. McIntyre, L. Gagliardi and W. J. Evans, Inorg. Chem., 2012, 51, 3613-3624.

16 (a) B. M. Gardner, D. M. King, F. Tuna, A. J. Wooles, N. F. Chilton and S. T. Liddle, Chem. Sci., 2017, 8, 62076217; (b) L. P. Spencer, E. J. Schelter, P. Yang, R. L. Gdula, B. L. Scott, J. D. Thompson, J. L. Kiplinger, E. R. Batista and J. M. Boncella, Angew. Chem., Int. Ed. Engl., 2009, 48, 3795-3798.

17 (a) D. P. Mills, F. Moro, J. McMaster, J. van Slageren, W. Lewis, A. J. Blake and S. T. Liddle, Nat. Chem., 2011, 3, 454-460; (b) V. Mougel, L. Chatelain, J. Pecaut, R. Caciuffo, E. Colineau, J. C. Griveau and M. Mazzanti, Nat. Chem., 2012, 4, 1011-1017.

18 (a) R. K. Rosen, R. A. Andersen and N. M. Edelstein, J. Am. Chem. Soc., 1990, 112, 4588-4590; (b) G. Nocton, P. Horeglad, J. Pécaut and M. Mazzanti, J. Am. Chem. Soc., 2008, 130, 16633-16645; (c) V. Mougel, P. Horeglad, G. Nocton, J. Pecaut and M. Mazzanti, Angew. Chem., Int. Ed. Engl., 2009, 48, 8477-8480; (d) P. L. Arnold, G. M. Jones, S. O. Odoh, G. Schreckenbach, N. Magnani and J. B. Love, Nat. Chem., 2012, 4, 221-227; (e) L. Chatelain, V. Mougel, J. Pécaut and M. Mazzanti, Chem. Sci., 2012, 3, 1075-1079; (f) A.-C. Schmidt, F. W. Heinemann, W. W. Lukens Jr and K. Meyer, J. Am. Chem. Soc., 2014, 136, 11980-11993.

19 (a) P. L. Diaconescu, P. L. Arnold, T. A. Baker, D. J. Mindiola and C. C. Cummins, J. Am. Chem. Soc., 2000, 122, 6108-6109; (b) B. Vlaisayljevich, P. L. Diaconescu, W. L. Lukens Jr, L. Gagliardi and C. C. Cummins, Organometallics, 2013, 32, 1341-1352.

20 (a) B. M. Gardner, J. C. Stewart, A. L. Davis, J. McMaster, W. Lewis, A. J. Blake and S. T. Liddle, Proc. Natl. Acad. Sci. U. S. A., 2012, 109, 9265-9270; (b) O. P. Lam, F. W. Heinemann and K. Meyer, Chem. Sci., 2011, 2, 1538-1547.

21 E. J. Schelter, P. Yang, B. L. Scott, J. D. Thompson, R. L. Martin, P. J. Hay, D. E. Morris and J. L. Kiplinger, Inorg. Chem., 2007, 46, 7477-7488.

22 A. J. Bridgeman, G. Cavigliasso, L. R. Ireland and J. Rothery, J. Chem. Soc., Dalton Trans., 2001, 2095-2108. 